Documentos: A plataforma do Projeto 


\title{
Um plano diferencial para o Brasil
}

\author{
$A Z I Z A B$ 'SABER
}

\section{Reflexóes preliminares e critérios}

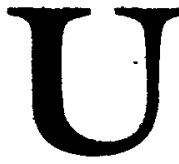

m plano nacional de reflorestamento, elaborado por critérios múltiplos e destinado a funçóes

diversificadas - comportando implantaçáo de

fitomassa, reflorestamento ecológico, reflorestamento corretivo e reservas de matéria-prima, para utilizaçáo racionalizada - por certo provocará receios e indagações de técnicos, ecologistas e políticos, legitimamente interessados na preservaçăo ecológica e no bom uso da terra. Acostumados que estamos em ver impingidos ao país programas e planós tecnocráticos, genéricos e prejudiciais, elaborados $\mathrm{em}$ relatórios de baixo nível đe abrangência científica e avaliação crítica, temos uma natural propensão para fundadas desconfianças. Passamos a exigir estudos de previsăo de impactos, no nível da dinâmica fisiográfica e ecológica, e em termos das conseqüências econômicas e sociais dos projetos. Tais exigências foram rapidamente absolvidas, porque têm sido transformadas em serviços de consultoria na maior parte das vezes parciais e dirigidos, a favor da aprovaçáo dos projetos. Distorçōes imensas se fizeram presentes nas audiências públicas, onde nem sempre tem sido possível qualquer discussão aprofundada das questóes mais controvertidas, criando-se apenas espaço para manifestaçóes diametralmente opósitas. Estamos, porém, no caminho certo para atingir um novo patamar de inteligência, à custa de uma multidisciplinaridade mais plena, e de uma metodologia suficientemente capacitada para internalizar a previsáo de impactos e o balanço dos custos/benefícios para a natureza, a sociedade, o país e a regiâo.

\section{Tipos de espaços geográficos e sociais no Brasil: vinculação do Projeto FLORAM.}

Em qualquer projeto que envólva o uso de espaços remanescentes do Mundo Tropical, é necessário possuir uma boa visão do mosaico de 
domínios de natureza existentes nos territórios nacionais considerados. Fato válido para África, Índia ou Malásia e Indonésia, como para o Brasil.

Entre nós, existe um razoável conhecimento da organização natural dos espaços herdados da natureza, em terras tropicais e subtropicais brasileiras. A descoberta das vocaçóes ecológicas de cada área nučlear dos espaços geográficos brasileiros é; porém, ainda muito incompleta, já que as áreas amazônicas do país vêm se constituindo em espaços de grande dificuldades para usos agronômicos rentáveis e auto-sustentáveis, obrigando-nos a uma busca insistente de modelos ecodesenvolvimentistas. Por muitas e variadas razóes.

Além do conhecimento básico dos domínios da natureza e seus ecossistemas, existe a necessidade de conhecer a tipologia dos espaços geográficos e sociais, criados por processos antrópicos ao longo dos tempos, e em face das condicionantes do subdesenvolvimento. Acontece que esse cruzamento de grandes cenários não é uma tarefa tẩo simples e transparente.

\section{Tipos de espagos geografficos e sociais do Brasil}

O conhecimento integrado e dinâmico existente sobre os grandes espaços geográficos que compóem o território brasileiro pode ser considerado até mesmo suficiente para respaldar a elaboração de projetos de interesse macrorregional. Muito mais complexo e difícil de ser visualizado, porém, é a setorização dos domínios de natureza no nível de uma criteriosa regionalização e de conhecimento detalhado da funcionalidade dos ecossistemas. Efetivamente, o grau de conhecimento sobre o mosaico de regióes que participam de uma condiçáo intra e interdominial é muito desigual e genérico. No entanto, é nessa realidade espacial que os planejadores, os técnicos e administradores vão operar no nível de uso de solo, na busca de modelos de glebas rurais, de reafeiçoamentos paisagísticos e ecológico-econômicos. Ou, no nível de reconhecimento de potencialidades locais e regionais, para projetos de silvicultura, florestamento ou reflorestamento. No caso particular do Projeto FLORAM, para vencer o desafio do baixo nível acumulado de conhecimentos geoecológicos, utilizamos largamente nossas experiências de pesquisas sobre o terreno a fim de reconhecer e mapear regiōes com maiores ou menores potencialidades de interesse para o Projeto. Foi importante e providencial a existência de uma cartografia temática, realizada em diversas escalas a respeito da vegetação brasileira, dos solos regionais, da geologia e geomorfologia, e, eventualmente, do uso potencial vocacional dos terrenos. 
Nosso teste final, porém, esteve sempre relacionado com o conhecimento dos tipos de espaço geográficos e sociais que compóem o país neste fím de década (1990). Para tanto, nosso referencial básico - utilizado à exaustão - foi a tipologia dos espaços geográficos de países subdesenvolvidos estabelecidá pelo geógrafo francês Bernard Kayser, da Universidade de Toulouse (1966). Mesmo que o Brasil apresente uma diversidade maior de espaços geográficos e sociais do que os listados pelo autor (regióes em vias de organizaçáo com grande presença da natureza, regióes de especulaçáo agrícola, bacias urbanas, regióes de planificaçăo por intervençáo econômica voluntária e, por fim, regióes auto-organizáveis e de organização complexa e alto padrão regional de desenvolvimento), sua classificaçáo tem o valor de um referencial importante para discussóos subseqüentes, projetadas para as mais diferentes questōes internas e externas dos espaços previamente identificados. Pensamos em propostas relacionadas a projetos múltiplos de infra-estrutura, controle ambiental diferenciado, propostas regionais específicas de políticas efetivamente desenvolvimentistas, incluindo modelos de ecodesenvolvimento e compatibilizaçáo de funçóes econômicas. E controle da poligonaçáo viária ou, ainda, a percepsáo de intermodalidades de transportes, de riquezas e pessoas, aconselháveis para cada caso.

Para atender o território brasileiro no seu conjunto - à altura desse fim de século -, haveria que completar os tipos de regióes propostas por Kayser, pelo menos com alguns espaços dotados de grande especificidade e dinâmica de atividades própria. Estamos pensando na longa faixa costeira do país que se desdobra em segmentos especiais vinculados às relaçóes de planalto e litoral; ou de núcleos urbanos e faixas de' lazer vinculadas com as hinterlândias mais ou menos distantes. Outro tipo de região é aquela que possui marcante diferenciaçăo climática no entremeio de áreas exaustivamente úmidas (tais como a dos sertóes secos do Nordeste) onde, porém, existem infra-estruturas urbanas, viárias e econômicas, suficientes para criar um quadro original de ordem demográfica, social e cultural.

O Nordeste Seco, pela influência das condiçóes climáticas e hidrológicas semi-áridas, comporta-se como um tipo de regiáo ecológica e humana, de forte vinculaçáo com os grupos culturais sertanejos, e os ritmos e condiçóes bioclimáticas e hidrológicas. Pela dimensáo territorial do domínio semi-árido brasileiro - avaliado em 800.000 a um milhăo dé quilômetros -, assim como pelo seu elevado índice demográfico; e a multiplicidade de cidades sertanejas, de apoio rural-urbano, suas hinterlândias polarizam para os grandes centros urbanos costeiros do Nordeste (Fortaleza e Recife, sobretudo). A regiáo comporta diversas bacias urbanas, hierarquicamente 
entrelaçadas, fato que contribui para manter a originalidade física $e$ ecológica da regiáo vista como um todo, e estabelece fluxos de direção múltipla, vinculados aos pólos de desenvolvimento regionais, mais próximos, ou nacionais, distantes. Aos quais se somam fatores pérfidos, quase insolúveis, ligados à rigidez da estrutura agrária regional e à incidência de secas prolongadas.

Um terceiro acréscimo à tipologia de Kayser é aquele relacionado a grandes faixas de sutura entre regióes ecológicas humanas $\mathrm{e}$ econômicas, muito diferentes e distanciadas entre si, onde se estabelece zonas pioneiras de um muito duvidoso sucesso econômico e social. Essas franjas pioneiras desvinculadas entre $s i$, em que a expansáo da fronteira fundiária é muito mais verídica do que a expansão da fronteira agrícola, ocorrem sobretudo em Rondônia, norte e nordeste de Mato Grosso, e sul do Pará. Trata-se, evidentemente, de um tipo de regiáo sujeita a modelos de ocupação empíricos e difusos, dificilmente controláveis, onde já se pode prever, após uma fase de grandes conflitos, o encontro de espaços para um reflorestamento híbrido, de alto valor ecológico e algum valor econômico.

No seu conjunto, os diferentes tipos de espaços geográficos e sociais que compóem o território brasileiro constituem heranças naturais e históricas, que solicitam planos regionais sob tratamentos inteiramente diversificados. $\mathrm{E}$, mais do que isso, no que respeita às grandes áreas da natureza tropical - relativamente pouco preparadas - há que adotar modelos totalmente diferenciados de tratamento, recorrendo-se aos princípios do ecodesenvolvimento. Trata-se, no caso, especificamente do grande espaço de terras baixas florestadas no norte do país - a Amazônia -, para a qual todas as melhores cabeças de cientistas preparados e sensíveis estáo voltadas, numa busca tão permanente quanto metódica, de modelos e estratégias de ecodesenvolvimentistas.

É compreensível que para as regióes dotadas de infra-estruturas sobrepostas - passíveis de serem consideradas espaços de organização complexa -, os padrōes de propostas e a elaboraçăo de estratégias devem seguir outros pontos de partida e roteiros de planificaçáo. Nesse sentido, é bom que se diga que o Estado de São Paulo, a despeito de sua gigantesca rede urbana, seus espaços agrários de grande expressáo e territorialidade, seu nível de urbanização e seu parque industrial, ainda assim apresenta reservas de espaços rurais suficientes para um projeto estadual de reflorestamento da ordem de quatro milhōes de hectares (Fundaçáo Instituto Florestal - SP). Se, em um quarto de milhão de quilômetros quadrados, na unidade administrativa de organizaçáo humana mais densa e complexa do país, pode-se encontrar uma somatória de subespaços da ordem de $\mathbf{4 0 . 0 0 0}$ 
$\mathrm{km}^{2}$, imagine-se quanto se poderá encontrar de espaços florestáveis nas diferentes regiōes que compóem o Brasil extra-amazônico.

Entre os casos extremos da Amazônia e Brasil de Sudeste/Brasil Sul, acontece todo um mosaico de situações específicas, em que se incluem regiōes extensivamente pouco favoráveis para a implantaçăo de florestas industriais (Nordeste Seco), porém extremamente necessitadas de reflorestamentos de interesse a um tempo ecológico, microclimático e econômico. Ou regióes ainda de fortes aptidóes para a implantaçáo de grandes volumes de fitomassas, como é o caso do domínio dos cerrados do Brasil Central, em seus dois ou mais subdomínios (áreas cristalinas/áreas sedimentares/áreas basálticas; ou áreas planálticas por oposição às áreas rebaixadas do tipo dos baixos chapadóes do Estado de Tocantins).

A exigência de um bom cruzamento entre os conhecimentos sobre as condiçóes dos espaços ecológicos com as formas vigentes de atividades, pressóes demográficas e somatória de infra-estruturas instaladas é fundamental para a correta elaboraçăo de um plano nacional de reflorestamento. De outra maneira, qualquer conjunto de

Entre nós, existe um razođivel conhecimento da organização natural dos espaços herdados da natureza.. diretrizes recairia no plano da teorização inconsequiente, afastando-se da necessária compreensão dos atributos dos espaços geográficos, vistos em sua totalidade. Um bom exemplo disso é o caso dos planaltos de araucária onde, em princípio, existiriam excepcionais condiçóes para reflorestamento por reintroduçáo de espécies locais. Entretanto, o fato dessa extensa regiáo planáltica do Sul do país ter se transformado em uma das mais vigorosas áreas de especulação agrícola do Brasil - centrada na monocultura da soja - acabou por limitar a viabilidade de um enriquecimento maciço da área, vista como um todo, por novos pinheirais. Mesmo assim, dadas as potencialidades da região para a reprodução das araucárias, há que se descobrir subespaços capazes de serem reenriquecidos por espécies nativas, nos bordos de platôs, vertentes de vales encaixados, manchas de solos rochosos, de baixa aptidão agrícola.

Nos planaltos interiores de São Paulo, a situação é mais grave e limitante para esforços de reflorestamento. $O$ café contribuiu para criar uma primeira e bem desenvolvida rede de cidades. Depois, após uma breve fase de diversificação agrícola (café, algodáo, cereais), sobreveio a extensão desmesurada dos canaviais e, por fim, uma alternativa entre canaviais, laranjais, sojais e cafezais. Fez-se, ao longo dessas vicissitudes agrárias, uma quase eliminação total das matas beiradeiras de córregos e riachos intraglebas. Por processos pluviais extensivos, corre solta a calda de defensivos agrícolas e produtos químicos, na direção dos canais de escoamento das microbacias

Estudos Avançados, 4(9) 
fluviais, existentes no interior das glebas. Os reservatórios escalonados comportam-se como sistemas semifechados no recebimento da massa residual de produtos tóxicos. A piscicultura restou praticamente inviabilizada e as possibilidades de solução para a qualidade das águas interiores tornou-se cada vez mais remota. A "pradarizaçáo" forçada dos planaltos outrora florestados ultrapassou todos os limites de segurança ecológica necessários. Os numerosos refúgios de biodiversidade, constituídos por matas de fazendas, foram extensivamente eliminados ou reduzidos. A queima dos canaviais, na fase de pré-colheita, obrigou a desmatamentos areolares, de grande amplitude e intensidade. A despeito disso tudo, existem numerosos subespaços passíveis de reflorestamento: bordos de platôs mais acidentados, manchas de solos inférteis, beira de córregos, riachos e rios em áreas não-canavieiras. Sem esquecer o entorno de reservatórios, as sub-bacias tributárias dos lagos de barragem no domínio dos morros em áreas não-industrializáveis, os interespaços disponíveis em faixas de redes urbanas em conurbaçáo, os setores predados dos parques estaduais, reservas florestais, e aqueles das serranias envolventes de regióes metropolitanas.

Enfim, existem prescriçóes totalmente diferentes conforme as peculiaridades e a organização humana dos espaços considerados. $\mathrm{Na}$ Amazônia, o problema centra-se na busca de soluçōes de manejo para garantir a preservação do máximo possível de florestas-em-pé e rios despoluídos. Em áreas como Sáo Paulo, Norte do Paraná, Rio de Janeiro, Minas Gerais, Santa Catarina e Rio Grande do Sul, a questão é outra; endereçando-se sobretudo para a reintroduçáo de espécies nativas, introduçáo de espécies arbóreas de crescimento rápido, reafeiçoamento paisagístico e ecológico dos subespaços deteriorados, reperenização das aguadas de primeira ordem e sistemática despoluição de rios e represas vítimas do desenvolvimento demográfico agigantado, da industrializaçáo poluidora e dos resíduos químicos das lavouras desenvolvidas nos planaltos interiores. Independentemente de que o esforço principal deva ser dirigido para a manutenção da produtividade das terras férteis e harmonia social entre o mundo rural e o mundo urbano. Planos de reflorestamento para países subdesenvolvidos, dotados de espaços territoriais inter e subtropicais, têm que ser, necessariamente, melhor engendrados, extremamente transparentes e, sobretudo, gerenciados por pessoas de grande inteligência, sensibilidade social, energia cultural e capacidade administrativa e profissional.

\section{Diretrizes para a Seleção dos Espaços}

Tais reflexóes foram a prévia básica que norteou a primeira fase do plano de reflorestamento para o território brasileiro, no nível de 
seleção de espaços e diferenciação de projetos. A própria tipologia dos reflorestamentos propostos foi estabelecida em funçăo do conhecimento dos diversos tipos de espaços geoecológicos e fitogeográficos do país e em se considerando as diferentes conjunturas de atividades atualmente vigorantes no interior de cada regiáo identificada e delimitada. Alguns pontos de partida foram essenciais para um correto desenvolvimento de um plano táo abrangente quanto certamente pretensioso, permanentemente sujeito a reciclagem.

- O plano prioriza a região extra-amazônica, no sentido de atenuar e, em muitos casos, bloquear a devastaçáo da grande herança biológica que o Brasil possui nas suas terras equatoriais. Tudo o que se puder fazer no sentido de encontrar espaços adequados para reflorestamento em áreas de solos degradados ou de baixa fertilidade natural, fora da Regiāo Amazônica, redundará, além dos benefícios específicos, em uma proteçáo estratégica para as grandes florestas nativas existentes no imenso Norte do país.

- O plano não possui endereço imediato para as terras do Grande Pantanal Matogrossense, mas sublinha o interesse direto da reintrodução de espécies nas chapadas envolventes do Pantanal no nível de todas as faixas de florestas-galerias e escarpas de planaltos (serras de Maracaju e Aquidauana). Insiste na preservaçáo total do revestimento florestal dos bordos escarpados da Chapada dos Guimarães. Neste sentido, desdobra-se em um plano de readensamento ecológico das florestas-galerias e num plano de proteçáo e reenriquecimento das faixas de florestas orográficas de Mato Grosso e Mato Grosso do Sul. Em caráter projetivo, intenta bloquear desmatamentos no corredor de terras inférteis do Vale do Guaporé, a NW do Pantanal.

- Em relaçáo aos sertóes do Nordeste, onde a semi-aridez domina de modo quase contínuo - três quartos de milhão de quilômetros quadrados, propóe-se um reflorestamento dual: que envolva a reintroduçáo de espécies nativas na beira alta dos rios intermitentes sazonários, onde outrora existiam matas ciliares - as matas da "c'raíba" - mas que pressuponha um grande esforço de introduçáo de espécies fortemente adaptadas às condiçóes climáticas e ecológicas da regiăo, tais como a algaroba, entre muitas outras a pesquisar. No que se refere à conjuntura atual da ocupação dos solos na "Zona da Mata", elaborar estratégias para a reintroduçáo de espécies nativas ao longo de vales (ou setores de vales) e encostas íngremes de tabuleiros. Para fins de implantaçóes industriais, induzir os empresários a selecionar espaços para suas instalaçóes em solos inférteis ou menos férteis, tais como os tratos de areia branca existentes em diferentes setores dos interflúvios tabuliformes. 
- O plano faz abstraçáo quase total das áreas dotadas de vigorosas e densas atividades agrícolas, tais como a Zona da Mata Nordestina, o interior de São Paulo e Norte do Paraná, os planaltos agrícolas de Mato Grosso do Sul e Mato Grosso, Oeste do Paraná e Santa Catarina, o Noroeste do Rio Grande do Sul e a regiáo de Bajé, e setores do Sudoeste de Goiás e Triângulo Mineiro.

Abstraídas três grandes regiōes dotadas de peculiaridades de consideração obrigatória - Amazônia, Pantanal, Sertóes Secos -, restam para tratamento e propostas específicas extensos espaços do Brasil Central, da periferia extrema da Amazônia, do Brasil Tropical Attântico, do Planalto das Araucárias e do domínio das pradarias mistas, nas coxilhas do Rio Grande do Sul. Trata-se de espaços dotados de grande diversidade geoecológica e em estado diferenciado de ocupaçáo dos solos por atividades agrícolas e pecuárias, em geral de baixa eficiência produtiva., $\mathrm{Na}$ realidade - como comprovaram as fichas técnicas elaboradas para cada subespaço identificado no interior dessas áreas ou domínios -, cada caso é um caso, a exigir propostas diferenciais de reflorestamento, complementação de atividades econômicas e tratamento paisagístico-ecológico. Nessa fase introdutória do plano de reflorestamento, limitamos nosso trabalho a identificar áreas e propor taxas razoáveis de reflorestamento, por nós designadas taxas de ocupafáo máxima toleráveis. Fizemos, ainda, um esforço particular para a conceituação diferenciada das taxas de ocupaçăo regional em face das taxas de ocupação intragleba.

Evidentemente, são propostas em aberto a serem reexaminadas, corrigidas e, sobretudo, recicladas com base no cenário total de atividades potenciais, previstas para o desenvolvimento integrado das regiōes consideradas. $O$ reflorestamento jamais é pensado como um tipo de cenário, monótono e homogêneo, descompromissado de outras tendências ou propostas compatíveis e desdobráveis, ou desamarradas em relação à dinâmica histórica.

\section{Tipologia dos reflorestamentos propostos}

O projeto brasileiro, nesse contexto, envolve a idéia de preservar o máximo possível as florestas tropicais da Amazônia e, de modo planejado e estratégico, efetuar a introduçăo de uma extraordinária fitomassa em áreas factíveis, a par com reflorestamentos ao longo do Brasil Tropical e Atlântico. Mesmo em relaçăo à Amazônia, onde há pouco a fazer em termos de reflorestamento no interior de grandes áreas ocupadas por florestas contínuas, encontram-se cinco ou seis áreas para projetos especiais, com funçóes múltiplas, a saber:

1. experiências com silvicultura na faixa depredada do "Corredor Carajás - São Luiz", para atender unidades siderúrgicas em 
Na Amazônia, o problema centra-se na busca de soluçôes de manejo para garantir a preservação do máximo possivel de florestas-em-pé e rios despoluídos.

implantação, evitando-se o uso de carvão vegetal feito com madeira de florestas nativas;

2. experiências de ampliação da silvicultura nos campos do Amapá, onde existem cerrados naturais "sub-standards", muito degradados, em situaçóes de difícil reversibilidade;

3. reaproveitamento contido das experiências florestais realizadas no "Projeto Jari", para efeito de utilização de seus padróes de tecnologia melhor sucedidos, e projetados para outras áreas do país;

4. proibir, por todos os meios, qualquer devastação de grandes glebas amazônicas para posterior implantaçáo de reflorestamento com espécies alienígenas e examinar, com extremo cuidado, a conveniência ou não de liberar glebas predadas, para fins de silvicultura industrial;

5. exigir seriedade e racionalidade na exploraçăo intersticial da madeira nobre no interior do grande contínuo florestal amazônico, consolidando a idéia de exploração auto-sustentada, em rodízio de $\mathbf{3 0}$ a 35 anos, sob rígido gerenciamento da tecnologia de florestas tropicais. Evitando-se, por todos os meios, práticas que redundem na compactaçáo dos solos regionais ou perda de biodiversidade. $\mathrm{E}$, finalmente, incentivo a plantaçóes vinculadas à fruticultura tropical, em espaços abertos expostos (castanheiras) ou $\mathrm{cm}$ espaços sombreados, periféricos a glebas já desmatadas (cacau, café, dendê).

Em qualquer plano de reflorestamento que pretenda abranger o maior número de espaços ecológicos do país, será certamente o Brasil de Sudeste - onde se estendiam as grandes matas designadas tropicais atlânticas - que oferecerá maiores desafios aos especialistas e planejadores.

Iniciando-se muito próximas da costa - a partir dos morros de pontas-de-praia - , as matas tropicais orientais e sul-orientais do Brasil atingiam as grandes escarpas terminais do Planalto Brasileiro (tipo Serra do Mar) e alcançavam compartimentos de planalto e serranias interiores, abrangendo espaços inteiros de bacias hidrográficas, tais como as dos rios Doce, Paraíba do Sul, Ribeira de Iguape, e Médio e Baixo Itajaí. As capitanias hereditárias foram estabelecidas em tratos das matas atlânticas. Para se atingir as terras interiores, ecologicamente diferenciadas, era necessário transpor setores costeiros dessas matas. A cana-de-açúcar se estendeu por toda a "zona da mata" nordestina, à custa da supressáo gradual da biomassa florestal que revestia os espaços ecológicos regionais, desde a Paraíba e Pernambuco até o Recôncavo Baiano. Muito mais tarde, o café provocou o 
devassamento dos morros, colinas e serranias florestadas da bacia do rio Paraíba do Sul, antes de avançar pelos chapadóes florestados do interior de Sáo Paulo e Norte do Paraná. O cacau desenvolveu-se, sob o sistema de culturas sombreadas, pelo Sul da Bahia e Norte do Espírito Santo, enquanto a devastaçáo de florestas para carvoaria destinada às siderurgias mineiras - contribuiu para imensas predaçóes em Minas Gerais, desde os confins da Bacia do Paraíba até as porçóes centrais da Bacia do Rio Doce. Fato parcialmente revertido nos últimos anos.

As matas atlânticas do Nordeste transicionavam rapidamente para as caatingas sertanejas, delas separadas apenas por faixas estreitas de matas secas e agrestes com caatingas arbóreas. Em Minas Gerais, as matas tropicais eram retidas nos sopés orientais do Espinhaço, além do qual estendiam-se intermináveis áreas de cerrados. No Brasil de Sudeste, em altitude, as grandes matas cedem lugar para os campos de cimeira e bosques de araucárias, enquanto o manto florestal se interpenetrava por vales e compartimentos rebaixados de relevo, abrangendo todo o Planalto Atlântico de Sáo Paulo, o Sul de Minas e os setores baixos do Planalto Atlântico do Alto do Rio Grande, antes de se adentrar por Sáo Paulo além, até o Norte do Paraná. Mas por todo esse espaço, fortemente compartimentado, por onde passou o café e implantou-se uma vigorosa agricultura, respaldada na mais densa rede urbana das Américas, estabeleceram-se ecossistemas perturbados e rios poluídos: agroecossistemas, sistemas urbanos, enquanto permaneceu uma porcentagem remanescente muito pequena de ecossistemas florestais do tipo da Serra do Mar. Disso resulta a necessidade de um reflorestamento híbrido para as regióes depredadas e reforço de estratégias para preservar a Serra do Mar e os esporóes da Serra da Mantiqueira e proteger um agrupamento disperso de matinhas situadas $\mathrm{em}$ áreas de baixadas, maciços costeiros, maciços insulares e borda de chapadóes interiores, do tipo das escarpas de cuestas tropicais (Serra de Botucatu, e suas extensóes).

As propostas de reflorestamento terão que ser necessariamente mistas e adaptadas às peculiaridades de cada setor dessa alongada e complexa fachada atlântica da América Tropical. Há que se readensar setores degradados das florestas atlânticas na faixa de transiçáo entre a Serra do Mar e os primeiros setores da morraria de Serra Acima. Um esforço particular de reflorestamento, com espécies nativas, deve ser dirigido para as cabeceiras de drenagem, situadas em áreas de morros transformados em pastagens pobres e maltratadas. Tudo isso tem um custo muito alto.

No entorno, evidentemente, dos belíssimos reservatórios criados no 
entremeio dos morros de vertentes arredondadas, desnudas de vegetação arbórea, existem condiçóes favoráveis para recomposiçăo de tratos das paisagens de beira represa, pela reintrodução de espécies nativas, em combinaçóes estudadas de plantio e em faixas de largura diferenciada, ao longo do perímetro total do lago da represa. Mas é, também, aconselhável que cada proprietário de terras, em áreas de morros e serranias, constitua uma pequena floresta de espécies de crescimento rápido - nos bordos e confins de seu sítio ou fazenda, à moda de uma cerca viva larga -, para garantir sombra e guarida para o gado de serviço e gado leiteiro e obter economia complementar para o orçamento da família ou da empresa, através da venda da madeira e da utilização da lenha. A área de implantação desses bosques espaçados náo deve ser superior a $15 \%$ ou $20 \%$ do espaço total das propriedades, exceçáo feita para o caso daquelas glebas situadas nas proximidades de instalaçóes industriais, relacionadas a celulose, papel ou placas.

É de todo necessário organizar o sistema híbrido de reflorestamento

Planos de reflorestamento parn paises subdesenvolvidos, dotados de espaços territoriais intere subtropicais, têm que ser, necessariamente, melhor engendrados... nas terras do Brasil de Sudeste e Brasil Atlântico Central, como reforço de atividade do meio rural empobrecido do Brasil Tropical. Consideramos como urgente $e$ inadiável o processo de reflorestamento no domínio dos morros, a fim de recompor e revitalizar os espaços herdados do período do café, hoje relegados à triste condiçáo de fazendolas produtoras de leite $\mathrm{C}$. Trata-se de uma das retaguardas mais degradadas e empobrecidas do país, ainda que localizadas há poucas dezenas de quilômetros dos setores mais industrializados e intensivamente urbanizados. $O$ resgate dessas áreas de baixa eficiência produtiva pode se iniciar dentro do espaço de um plano nacional de reflorestamento.

\section{Condicionantes regionais para um desenvolvimento com base em reflorestamentos}

Identificadas as áreas dotadas de maior potencial para reflorestamento, tornou-se fácil examinar quais as exigências de cada espaço delimitado para fins de desenvolvimento florestal. Cada tipo de proposta básica para as diferentes áreas selecionadas internaliza as funçóes que se deseja atingir $e$ inclui uma visáo específica dos impactos previsíveis. Trata-se de uma metodologia que abrevia tempo e orienta discussáo, sem fechar qualquer proposta nova, de ordem construtiva, crítica ou supressiva. Enfim, uma aplicação de ciências, feita com a melhor $\mathbf{e}$ a maior das preocupaçóes éticas e sociais.

Os tipos de reflorestamento identificados foram:

1. reflorestamentos corretipos destinados a solucionar problemas

Estudos Avançados, 4(9) 
emergentes ou realizar tratamento ecológico-paisagístico de regiōes críticas, incluindo reafeiçoamentos programados, reperenizaçáo de drenagem ou bloqueio de desertificaçáo antrópica;

2. reflorestamentos por silvicultura de grande extensaio, sob topologia ou mosaicos estudados para cada gleba e situaçáo paisagística e ecológica, envolvendo fitomassa suficiente para reter Carbono e volume de matéria-prima de utilização constante no nível de $7 / 8$ de permanência (por rebrota ou replantio);

3. reflorestamentos bibridos para provocar melhoria da dinâmica da natureza regional, tais como reperenização da drenagem de cabeceiras, proteção contra a evaporação excessiva das águas tombadas e dos fluxos de águas correntes e, doutra banda, através de programas intraglebas, suficientes para criar um recurso novo para os proprietários rurais de áreas fortemente predadas (tipos "morros" desflorestados das bacias dó Paraíba do Sul e Vale do Rio Doce). Cada um desses tipos envolve subtipos e precauçóes próprias e obrigatórias, a fim de evitar conflitos entre as funçóes mais propriamente ecológicas e aquelas mais diretamente pragmáticas. Trata-se de reflorestamentos organizados, porém restritos, de pouco interesse econômico e grande interesse social.

O caráter de megarreflorestamento proposto para algumas áreas existentes no interior do domínio dos cerrados - sob taxa de oc upaçáo máxima de até $30 \%$ - pode se constituir na grande colaboração brasileira para o seqüestro do gás carbônico, através de apreciável fitomassa, num exemplo que poderá ser seguido por outros países tropicais e sob a condição de que as naçōes fortemente industrializadas elaborem estratégias eficientes para minimizar os efeitos negativos relacionados à carga industrial por eles implantada è em funcionamento há mais de um século. No caso, trata-se certamente de florestas produtivas, de grande força de retorno, em termos de economicidade.

\section{A zona costeira atlântica do país e o Projeto FLORAM}

Na elaboração do Projeto FLORAM, tivemos um cuidado especial com os espaços litorâneos mais próximos à linha de costa. Sabemos, de antemáo, que certas áreas costeiras dos litorais equatoriais e subequatoriais nãó podem receber qualquer tipo de interferência antrópica, a náo ser o reenriquecimento da fitomassa da retroterra 
outrora florestada. É o caso da costa de "rias" do noroeste do Maranhäo, Pará e Amapá, onde os manguezais, desenvolvidos nos últimos 6.000 anos A.P., colmataram as margens dos numerosos estuários e deslancharam as únicas planícies de marés com mangues frontais existentes em toda a costa brasileira. Trata-se de um setor litorâneo típico para uma preservaçáo integrada, sob a forma de Parque Nacional Costeiro, ou unidade de preservação similar. Sobre o assunto, aliás, existe total consenso na área técnica e científica brasileira.

Existem, porém, outros tipos de espaços costeiros que efetivamente já vêm recebendo iniciativas extensivas de florestamento e reflorestamento, por iniciativas empresariais. Estão, nesse caso, as extensas plantaçōes da Companhia Vale do Rio Doce è dà Aracruz Celulose, em terras baixas onduladas do leste do Brasil tropical atlântico (Espírito Santo e Bahia). Trata-se de algumas das mais densas; extensas e bem-sucedidas áreas de silvicultura do país. Mesmo assim, houve uma excessiva ocupaçáo dos espaços costeiros, através de taxas de ocupaçáo intraglebas muito elevadas. A análise dos modelos de ocupaçáo do espaço existente nas áreas de reflorestamento da faixa Espírito Santo e Bahia torna possível uma revisāo dos cenários criados, com vista a modelos ecológicos mais adequados e, sobretudo, menos criticáveis. $O$ ideal para a regiáo seria uma taxa de ocupaçáo regional de florestamento da ordem de 30 a $35 \%$. E, nó nível de ocupaçáo intragleba (ou gleba a gleba), em total de, no máximo, 35 a $40 \%$. Além do que, seria desejável uma organizaçáo interna da gleba incluindo espaços preserváveis para a vegetação nativa, espaços de florestamento, $e$ um certo percentual de terras para atividades agrárias. Em qualquer hipótese, deveria ser evitada uma implantação de florestas industriais abrangendo todos os espaços de vertentes $e$ interflúvios. O esquema mais habitual, existente no Brasil Leste, é o de preservar florestas nativas nos eixos dos vales e bases de vertente $\mathrm{e}$ colocar florestas plantadas por todos os setores mais elevados da topografia. Por numerosas razōes, preconizamos uma fundamental modificação nesse modelo, visando um ganho de economicidade social regional, sem maiores perdas da economicidade empresarial.

Úm outro caso de silvicultura em franca expansáo na zona costeira do Brasil é aquele que vem se processando na grande restinga do Rio Grande do Sul. O eixo dessa imensa restinga é formado por um terraço de construção marinha (de idade possivelmente pleistocênica), onde existem condiçóes favoráveis para a implantaçăo de florestas de pinus. Até há poucos anos atrás, a região era um espaço agrário tradicional, altamente descontínuo, dedicada à plantação de cebola 
(dita "tipo Rio Grande" ). Os pequenos "cercados" dos plantadores - sofridos plantadores de cebolas - não tinham muitas condiçóes de economicidade plena, devido aos preços aviltados do produto e o encarecimento dos serviços de transporte. Assim, foi fácil - por diversas operaçóes financeiras e de "teniência de la terra" - estender plantaçóes industriais de pinus, em detrimento dos antigos cenános agrários tradicionais. Um plano regional de ocupaçáo do espaço, com alguns pressupostos indutores, poderia evitar o tamponamento progressivo e generalizado dos espaços árenosos da grande restinga, envolvendo taxas de ocupaçáo intragleba, reservas sincopadas de espaços ecológicos (palmares), e convivência das novas plantaçōes com as atividades rurais tradicionais da faixa Mostardas/Tavares/São José do Norte.

No Projeto FLORAM, através de uma visão crítica prévia, deixamos de sinalizar os espaços costeiros constituídos por tabuleiros e colinas (Leste do Brasil) ou grandes planícies de restingas (Sul do país) como sendo áreas passíveis de ampliaçáo da silvicultura para fins industriais. Aí já existem grandes plantaçōes, segundo um modelo agrariamente criticável, que não pode ser incentivado $\mathrm{em}$ sua expansão. A economicidade empresarial conseguida não deveria ser um parâmetro para a multiplicaçáo do modelo, por grandes espaços da retroterra costeira imediata. Sobretudo enquanto não for encontrado uma fórmula híbrida, socialmente mais condigna e aceitável. No caso, a partir de uma filosofia de ecodesenvolvimento, há que apelar ainda para os princípios de uma "social forestry".

Muitas áreas costeiras do Brasil tropical e subtropical atlântico solicitam modelos particulares de reflorestamento, à custa de essências nativas, sob a forma de enriquecimento e readensamento de florestas pluviais. Estáo nesse caso: os maciços costeiros e os maciços insulares da regiáo litorânea sul - sudeste do Brasil, constituídos por morros de diferentes alturas, esporóes de serras e antigas cristas desvinculadas das serranias interiores por processos de desvinculaçáo, relacionados com a história quaternária da costa. A despeito da fortíssima pressáo da especulaçáo imobiliária sobre os mais diversos tipos de cenários costeiros há que se descobrir estratégias diferenciais para preservar $e$ proteger o máximo possível das coberturas florestais remanescentes. Para obter bons resultados nessas empreitadas há que se elaborar "master plans" de controle regional dos espaços litorâneos e sublitorâneos, incluindo planos diretores detalhados para os espaços insulares onde existem grandes cidades, algumas das quais capitais administrativas de estados brasileiros (Florianópolis, Vitória, São Luiz, Santos/São Vicente, Guarujá). As escarpas florestais - tipo Serra do Mar - devem ser sumariamente tombadas. 


\section{Reflorestamentos de beiras de reservatórios e fomento da arborização urbana}

Através dos princípios que nortearam o Projeto FLORAM, ficou decidido que se reservaria um espaço particular para o reflorestamento da beira de reservatórios, bordos de rodovias e arborização intra e periurbana, em cidades de diferentes portes. Para cada um desses tipos de reflorestamento, pertencentes a um agrupamento especial de áreas a receber introduçáo de fitomassas, deverá ser feito um estudo específico e inais detalhado. Mesmo assim, em caráter introdutório, julgamos indispensável pontualizar as principais questōes relacionadas a barragens, rodovias e aglomerados urbanos, em termos de exigências e possibilidades de reflorestamentos particularizados.

As propostas de refiorestamento terão que ser necessariamente mistas e adapatadas ds peculiaridades de cada setor dessa alongadae complexa fachada atlântica da América Tropical
No que respeita a barragens, as situaçóes são muito diversas; quer se considere um reservatório implantado no entremeio de morros desmatados, um grande açude do sertão do Nordeste ou uma barragem feita no coração das selvas amazônicas, onde não houve tempo nem clarividência para remover a própria fatia de florestas que iria receber a inundação derivada do barramento fluvial. No caso das barragens em áreas de morros, desprovidos de sua antiga cobertura florestal, existe conhecimento acumulado, estratégias bem-elaboradas e exemplos de grandes sucesso nas implantações (barragens da CESP, no domínio dos morros do alto vale do Paraíba). Já no que tange aos grandes açudes dos sertōes secos do Nordeste, a situação é mais delicada, pela dificuldade de se encontrar espécies arbóreas adaptadas a conviver com as secas, em encostas das colinas sertanejas. Ainda que, para os vales de jusante, dotados de planícies aluviais, se possa obter uma densa e notável fitomassa de fruteiras e palmáceas (coqueiros, mangueiras e bananeiras), a par com alguns limitados espaços agrários de razoável produtividade. Em relação a processos de reflorestamento $\mathrm{em}$ áreas de reservatórios do Sul do país, situados em planaltos basálticos e em áreas dotadas de solos férteis (terras roxas), a situaçăo é extrèmamente delicada. Ocorreram casos em que os fazendeiros da área de entorno do reservatório estenderam sojais até a linha de contato entre a água e os espaços plantados. Outros remanejaram, por conta própria, a margem dos lagos artificiais para conseguir alguns milhares de metros a mais de espaços agrícolas úteis. A calda de partículas ferromagnesianas que entra na massa d'água dos reservatórios, que é liberada para jusante na direção dos rios pertencentes às bacias do Uruguai e Paraná, é incalculável em termos de perda de solos. Tudo por incúria dos órgãos e superintendências regionais no gerenciamento e controle das margens de reservatórios. Após o fechamento da barragem fluvial e enchimento dos lagos artificialmente formados, libera-se todo o entorno para os 
proprietários rurais que, de antemão, já foram ressarcidos (ou têm garantias de ressarcimento) pela porçáo das terras afetadas pela submersão. Não tendo sido previsto um cinturão de proteçăo ecológica (ecological buffer zone) em forma de tampão e filtro entre as águas e as terras agrícolas, acontece de tudo em termos de conflitos de procedimento e especulação, após o fechamento da barragem.

Seria bem mais fácil de se resolver esse quadro repetitivo de anomalias e conflitos, caso houvesse uma reflexăo mais séria e permanente sobre os fatores impactantes ligados à constituição de barragens $e$ reservatórios. Falta inteligência, conhecimento integrado, espírito público, energia cultural e capacidade de previsáo de impactos e proposiçáo de soluçóes, entre a grande maioria dos superintendentes de organismos regionais de desenvolvimento no Brasil. Urge realizar uma campanha para uma substancial melhoria desses padróes de comportamento, com vistas a uma efetiva modernizaçáo da administração pública brasileira.

Os conhecimentos disponíveis para o uso da arborizaçăo viária, entre nós, sấo razoavelmente desenvolvidos, porém impotentes para aplicaçöes corretas nos diferentes domínios de natureza que individualizam o território brasileiro. Existe a necessidade de se criar um conjunto de padróes ou modelos de arborização adaptados às circunstâncias físicas e ecológicas de cada região do país, consideradas suas peculiaridades físicas, ecológicas e sociais. Não há como estender padrōes utilizados com sucesso no Rio Grande do Sul ou Paraná para distantes regióes do Nordeste, Brasil Central ou Amazônia. Por outro lado, o advento das rodovias com quatro, seis ou mais pistas, e a liberação quase total das velocidades nas estradas brasileiras, obrigam a adoção de padróes de arborização que sejam a um tempo criativos e funcionais. Náo há como fugir disso, a despeito da reação e do simplismo que predominam entre os cultores de tal tipo de planejamento. $O$ tradicional e rotineiro, herdado de velhas posturas e textos descompromissados, somente serve para reciclar uma arcaica linha de pesquisa que deve ser totalmente modificada.

Há que começar pela abordagem dos problemas mais críticos. Com o advento dos estudos sobre células de calor urbano, tornou-se necessária uma percepção mais aguçada dos problemas microclimáticos ligados a rodovias de grande interferência no clima das áreas metropolitanas. Existem setores inteiros de grandes cidades afetadas pelo excessivo tamponamento de solos, pela ampliaçáo de artérias centro - bairro e circulaçáo externa (tipo saída da Dutra em Guarulhos, a Av. Brasil no Rio de Janeiro) e algumas avenidas de fundo de vales nà Grande Sáo Paulo. Tais faixas de trânsito intenso, 
comportando seis pistas centrais e quatro laterais, constituem-se no caso mais grave de interferência climática local existente no corpo urbano de nossas áreas metropolitanas. Tudo porque os sucessivos acréscimos de pistas asfálticas, construídas por cirurgia em áreas de alta valorização do solo urbano, atropelam o processo de arborizaçáo, de modo constante e deliberado. Entre conseguir faixas de terrenos para novas pistas e prever subespaços para aléias ou bosquetes de árvores previamente selecionadas, prefere-se esquecer qualquer preocupação ambiental, de alta pertinência. E, assim, a célula de calor urbano se intensifica e se densifica, criando um desconforto a mais para os habitantes da cidade: odores das marginais somados à acentuaçăo do calor urbano, sobretudo no verăo.

\section{Arborização urbana e periurbana}

A arborizaçáo urbana possui uma velha e ativa tradiçăo no Brasil. De Norte a Sul, as cidades brasileiras têm experiência acumulada sobre áreas verdes, incluindo praças e jardins públicos, implantados em diferentes épocas. Uma consciência de longa maturação determina um cuidado especial pelas árvores, seja numa pequena cidade do sertảo nordestino, uma cidade de fronteira no Rio Grande do Sul ou em um pequeno centro urbano da beira alta do Pantanal Matogrossense.

Numa abordagem inicial, mais abrangente, a arborizaçăo de organismos ou ecossistemas urbanos exige consideraçóes de diversas ordens, a saber: 1. fatos relativos a áreas verdes e espaços abertos intra-urbanos; 2. fatos de interesse ambiental periurbano; 3 . fatos relacionados com uma série de revisão do destino das reservas de áreas verdes, inclusive nos projetos de loteamento intra ou periurbanos, $\mathrm{e}$ fatos e estratégias relativos à minimizaçăo dos processos de conurbaçáo regional.

Evidentemente, para cada uma dessas linhagens de fatos, as propostas de arborizaçáo e florestamento adquirem padróes e diretrizes diferenciadas. Há que ter extremo bonı senso e energia cultural nas propostas de paisagismo ecológico dirigidas para as grandes periferias de cidades brasileiras. A ausência de entendimento da ecologia urbana das áreas metropolitanas, no contexto do subdesenvolvimento, pode invalidar ou distorcer qualquer proposta muito assimétrica ou socialmente simplória. Além do que, o processo está sujeito aos modismos e a mais desenfreada demagogia dos sistemas políticos lócais ou regionais. O projeto do grande Parque Ecológico do Tietê em Sáo Paulo foi transformado em "Clube da Nossa Turma", por aduladores profissionais. O projeto do Parque "Chico Mendes", 
fruto de uma idéia e de um planejamento exemplares, na base de longas conversaçóes com as comunidades residentes, esteve ameaçado da intrusáo de funçóes incompatíveis, pelo modismo e falta de ética e flexibilidade de profissionais de outras áreas. Sobrou a experiência de que a demora na implanta̧̧ão de um bom Plano favorece $o$ advento de propostas parasitárias, travestidas de funçóes aparentemente humanitárias, sob a forma de um rolo compressor, que nāo admite alternativas.

Entre os planos de arborização e reflorestamento, passíveis de consideração imediata, encontram-se aqueles relacionados à criaçăo de tampōes florestados ou grandes bosques nas fạixaș intermunicipais sujeitas a fortes $\mathrm{e}$ incontroláveis processos de conurbaçáo. Em áreas de redes urbanas densis e pouco espaçadas, como aquelas ocorrentes no médio vale do Paraíba paulista, ou entre Campinas e Limeira, ou mesmo em "praias grandes" ou "ilhas compridas". existem : possibilidades únicas de se exigir implantaçóes florestais planejadas para evitar a expansão desmesurada da urbanizaçáo e ou industrializaçāo. Tais propostas interessam sobretudo aos espaços administrativos das áreas de organizaçáo complexa de São Paulo, Norte do Paraná e zonas costeiras do Rio de Janeiro, Santa Catarina, Pernambuco, Espírito Santo e Rio Grande do Sul, e São Paulo. Caso não se atendam, com a rapidez e energia necessárias, os setores críticos dos eixos viários que propiciaram os processos de conurbaçáo - no modelo do médio vale do Paraíba -, nunca mais haverá estratégia capaz de reverter ou atenuar a caminhada para uma indesejável aldeia global.

\section{Impactos económicos e sociais}

O Brasil é um dos poucos países do mundo que possui dimensóes espaciais suficientes para desenvolver um plano de reflorestamento de grande escala, sem prejuízo de todas as outras atividades. Entretanto, num plano de tal ordem de grandeza, envolvendo a meta da implantaçáo de uma gigantesca fitomassa - em um espaço de tempo relativamente curto -, deixa margem para grandes receios em relaçáo a diversos impactos. Existem níveis de risco a serem examinados com o maior cuidado possível, na base do conhecimento das condiçōes de manejo da silvicultura e das respostas ecológicas de cada área considerada e cada espécie ou clone em cogitaçáo. Mas também existe a necessidade de se considerar, sob análise aprofundada, a questão dos impactos econômicos. Seria pérfido programar um reflorestamento de grande extensão que viesse redundar em benefícios assimétricos apenas dirigidos para os interesses do setor industrial. $O$ aviltamento dos 
O Brasil é um dos poucos países do mundo que possui

dimensōes espaciais suficientes para desenvolver um plano de reflorestamento de grande escala..

preços da matéria-prima não beneficiaria a ninguém, dentro das comunidades residentes e, sobretudo, em relaçáo aos representantes da força de trabalho ligada às diferentes operaçóes da silvicultura e atividades agropastoris. Esse alerta fortalece a idéia de que o plano de reflorestamento deverá ser acoplado com propostas paralelas de desenvolvimento regional. Não abdicamos da idéia de um verdadeiro planejamento integrado que implique em um feixe de propostas, beneficiando a estrutura agrária como um todo. Um cenário em que se alternem espaços silviculturais, uma agricultura modernizadora e flexível à diversificaçáo; uma pecuária melhorada, e as indústrias de transformaçáo e processamento, beneficiadoras dos produtos primários, visando maior valor agregado. Paralelamente, esforços deverão ser dirigidos para a implantação de núcleos de apoio para os trabalhadores rurais, onde haja espaços de lazer e, sobretudo, escolas e equipamentos culturais (salóes comunitários, pequenas bibliotecas, auditórios, espaços para música).

A questão dos recursos necessários para um plano de reflorestamento táo amplo e diversificado começa pela estratégia de alocaçáo de recursos. Envolve, também, a mobilizaçáo de um conjunto de • instituiçóes-chave do Estado e da Sociedade. Temos certeza que um plano bem-elaborado - factível e dotado de credibilidade - terá respaldo nacional e, certamente, internacional. Dependerá, porém, basicamente de um governo arejado e esclarecido, capaz de pensar o país como um todo, ao nível de seus diferentes espaços ecológicos e sociais: nas suas estruturas regionais e na sua territorialidade diferenciada; na composiçăo de seu mundo físico, biótico e humano; na funcionalidade de sua vida econômica e social. E, em face das instáveis conjunturas que pontuam, diferencialmente, a vida dos brasileiros nesse fim de século.

\section{Atrativos e diretrizes para um soçial "forestry"}

A possibilidade de incentivar as pequenas e médias propriedades para incluir o plantio de árvores no interior de suas glebas tem sido remota. Houve tempo em que se considerava uma fazendola bem cuidada aquela que sofreu desmatamento total para a formaçáo de pastos em morros. Após a decadência dos cafezais, nas regióes serranas do vale do Paraíba, ocorreu um aviltamento generalizado do preço da terra rural. Para não falar, evidentemente, da profunda queda do valor dos imóveis nas cidades nascidas à sumbra do ciclo do café (Bananal, Areias, São Luiz do Paraitinga, Lagoinha, Jambeiro, Paraibuna, Monteiro Lobato - ex-Buquira). Tornou-se fácil a aquisiçăo de fazendas de diferentes portes por criadores vindos de áreas de velha tradiçáo pecuária leiteira. E, no ensejo de transformação de velhas 
fazendas de café em pastagens de morros, produziu-se um novo agroecossistema vulnerável e de rentabilidade efêmera.

Os cafezais foram erradicados, capoeiras foram eliminadas e pastos se estenderam por encostas e altos da morraria arredondada, dominantes na regiáo. Em uma situação de espaços geomorfológicos, dotados de rochas profundas e generalizadamente decompostas, a regiăo como um todo ficou sujeita a açóes erosivas de diferentes graus de intensidade. Rapidamente, a capacidade de pastejo por hectare diminuiu a rentabilidade da atividade pecuária, transformando a regiáo em múltiplas bacias leiteiras empobrecidas. Uma outra leva de personagens - desta vez urbanos - dotados de excedentes de capitais, ganhos em múltiplas atividades nas cidades de melhor infra-estrutura, acabou por adquirir fazendas ou pedaços de propriedades para fins de lazer ou segunda residência, revalorizando as terras com objetivos não-rurais. Restou, no domínio dos morros, um quadro rural relativamente complexo, constituído por velhas famílias empobrecidas, dotadas de alguma experiência agrária, acrescidas de recém-chegados dispostos a organizar suas glebas para o lazer familiar, sem maiores preocupaçóes com a rentabilidade. Uns e outros, desde as áreas de morros da bacia do Paraíba do Sul, até as encostas ocidentais da Mantiqueira e a bacia do rio Doce, podem receber o impacto prioritário de um reflorestamento híbrido.

Cumpre reflorestar as cabeceiras de drenagem, os canais de escoamento dos pequenos riachos, a beirada alta das planíciés fluviais (em alvéolos ou calhas), os setores mais íngremes $\mathrm{e}$ úmidos das encostas de morros (outrora chamadas de "costa noruega", por serem mais frias, úmidas e sombreadas). Trata-se de um modelo de reflorestamento ecológico endereçado aos setores críticos dos espaços geomorfológicos, para sucesso do qual bastaria um esforço concentrado das "casas de lavoura" e orgáos similares, preexistentes na administração dos Estados. A difusáo do modelo pode ser iniciada através de um certo número de "casas da lavoura", sediadas em localidades-chave das regiōes serranas de São Paulo, Minas Gerais, Espírito Santo e Rio de Janeiro. Numa listagem que possibilite instalaçōes progressivas.

A estratégia básica para se obter esse modelo ecológico de reflorestamento - com um certo número de essências nativas de crescimento relativamente rápido - está em se fomentar, paralelamente, um determinado percentual (da ordem de 10 a 20\%) de plantio de réstias ou bosquetes de florestas energéticas. Para tanto, será necessário propor o plantio de gordas cercas vivas, com eucaliptos ou pinus, em setores adequados das margens das propriedades. E, 
eventualmente, alguns bosquetes de árvores espaçadas, variando entre 0,5 a 2 hectares, no máximo, para fornecimento de madeira para fins internos da propriedade, sombra e abrigo para o gado leiteiro. Para fornecimento de lenha ou carvão para vendas restritas ou uso interno, deveriam ser reservados alguns setores das margens da propriedade, onde se pudesse cortar árvores e garantir a possibilidade de permanência de uma certa fitomassa, através de processos de rebrota ou replantio.

As dificuldades para reintrodução de espécies nativas, em faixas de florestas-galerias ou matas beiradeiras degradadas, exigem um conhecimento prévio dos principais ecossistemas de fundo de vale e beira-rio, existentes de Norte a Sul, no Brasil. Para reenriquecer tais faixas de vegetação, é necessário, no mínimo, obter informes sólidos sobre a estrutura, composiçăo, gênese e funcionamento dos ecossistemas considerados. Năo há como, na base do conhecimento de uma só floresta-galeria, extrapolar para as muitas florestas beiradeiras do país.

A combinação do reflorestamento dos setores críticos com essências nativas e dos setores periféricos com o plantio de espécies arbóreas, adaptados e de crescimento rápido, sem abranger mais do que 20 ou $30 \%$ do espaço total da gleba, serviria como fator de reperenizaçáo das aguadas; acréscimo de produçáo própria de madeira, lenha e carvão; ampliaçáo relativa de orçamento familiar; sombra e água para o gado em pastos de morros. E, eventualmente, para o deslanche de atividades artesanais com a madeira produzida; feitura de móveis rústicos, marcenaria padronizada cooperativamente, cochos, moiröes de cerca, cercados de hortas, currais, ranchos, silos para o milho, melhorias das habitações, entre outras muitas possibilidades. Através desse caminho, estaríamos alcançando o cerne das propostas ditas de "social forestry", que possuem igual interesse no Primeiro como no Terceiro Mundo. Para não fazer alusão à mudança dos tristes cenários paisagísticos entrosados com uma nova dimensão cultural de conforto, produtividade e independência econômica e financeira. É evidente que para alcançar tais níveis de modernização haveria que paralelizá-los com processos de fomento agrário, educação rural, formaçáo de hortas e bancos de sementes, postos de saúde, salóes públicos para discussóes comunitárias, associaçốes desportivas e sistemas contidos e bem-estudados de incentivos. Não adianta preconizar uma "social forestry" sem conhecer a história do empobrecimento dos espaços agrários, para os quais o processo é dirigido. Nem tampouco existem chances de melhoria e sucesso dos planos, sem preconizar um feixe de iniciativas paralelas para uma efetiva modernizaçáo agrária e cultural das campanhas marginalizadas. 


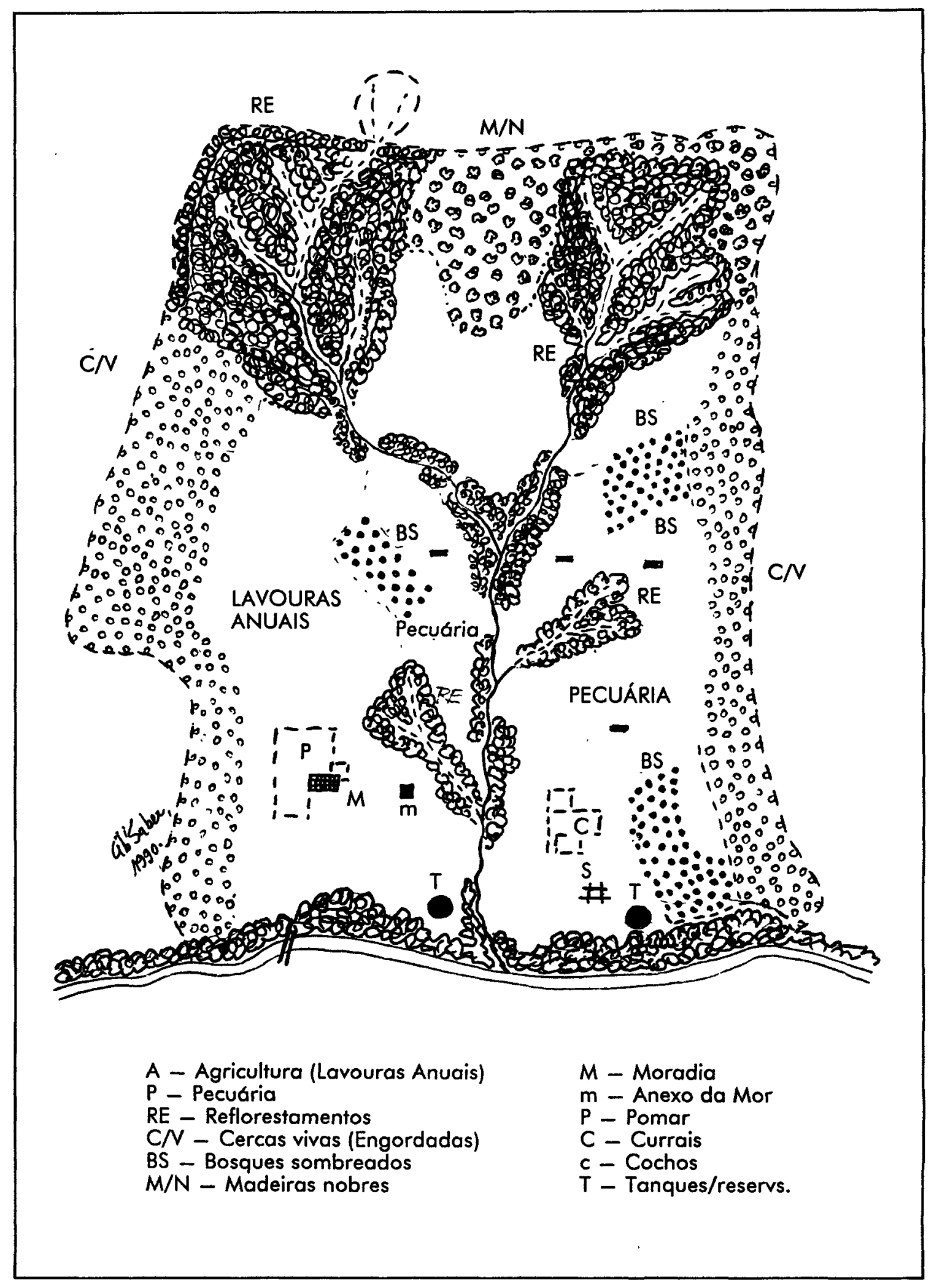




\section{Agentes e fatores multiplicadores: banco de germoplasma, hortos e centros de difusão}

O primeiro passo na constituição de um plano diferenciado de reflorestamento reside na multiplicação de bancos de germoplasmas, para garantir o uso e o fornecimento de mudas para a implantaçáo de diferentes projetos. As companhias que se dedicam ao florestamento de interesse industrial ou energético já dispóem de seus próprios hortos, alguns dos quais gigantescos. Mas, evidentemente, elas năo podem arcar com o peso da responsabilidade de fornecer mudas para os diferentes tipos de florestas previstos por um projeto da amplitude e das pretensóes do FLORAM.

A primeira providência seria a de estimular a formação de bancos de germoplasma, sob três categorias funcionais: 1 . banco de mudas para o desdobramento de espécies arbóreas de crescimento rápido, adaptáveis a diversos ambientes fitoclimáticos do Brasil e envolvendo agrupamentos de clones diversificados; 2 . bancos de mudas de espécies nativas regionais, trabalhados em centros estrategicamente dispostos no território brasileiro, para atender as exigências da reintrodução de espécies em pontos críticos de propriedades rurais, sob assistência técnica especializada e flexível; e 3. bancos de germoplasma híbridos, implantados em municípios cabeças-de-região, incluindo setores para desdobramento de espécies alienígenas, e setores para a multiplicaçáo de mudas de plantas nativas, escolhidas dentro de algumas dezenas de espécies arbóreas regionais.

É quase certo que, na base do conhecimento acumulado, se possa organizar grandes hortos para pinheiros-do-paraná, eucaliptos e pinus ditos tropicais. Mas todo cuidado é pouco no planejamento, constituiçáo e manejo dos bancos de germoplasmas que comportem seleções de plantas realizadas no interior da própria biodiversidade regional. Para isso, a exigência de estratégias especiais torna-se um procedimento indispensável. Na organizaçáo e implantaçăo dos hortos, há que contar com os mateiros catadores de sementes ou plântulas, experientes em percorrer o interior de matas remanescentes; com a devida autorização de proprietários ou autoridades responsáveis por reservas florestais, parques ou estaçóes ecológicas. Por outro lado, é preciso escolher bem o sítio do horto, em locais onde exista uma casa disponível ou uma simples edificaçăo construída para ser a sede do banco de mudas; onde haja espaço para a guarda do banco de sementes, e para o centro de fornecimento criterioso dos produtos vivos a serem endereçados para diferentes tipos de glebas, sob diferentes pequenos projetos de implantação.

A formaçăo de uma grande quantidade de mudas não é suficiente para 
fazer andar o grande Projeto. Há que engendrar critérios, avaliar corretamente as disponibilidades de cada gleba para efeitos de um florestamento ou reflorestamento, e acompanhar discretamente $o$ desenvolvimento dos pequenos projetos, simples e criativos, endereçados para cada propriedade rural, segundo seu tamanho e sua compartimentaçáo topográfica, edáfica e ecológica. Para obter sucesso coletivo nas implantaçóes, urge selecionar os municípios para a localizaçáo e funcionamento dos bancos de germoplasma, organizando-se estratégias locais ou regionais para a difusão do modelo, reciclagem das açóes e gerenciamento do Projeto. Evidentemente, porém, a administraçáo do Projeto somente teria viabilidade de implantaçáo se fosse realizada por um pool de esforços de instituiçóes competentes do governo, em diferentes níveis. $O$ Projeto em nível macro, em sua diversidade e amplitude deve ser federal; o detalhamento dos projetos regionais deve ser estadual, exigindo entrosamento obrigatório entre as diretrizes do FLORAM e o planejamento preexistente para reflorestamento no âmbito do espaço administrativo dos Estados. E, por fim, cabeças-de-regiāo e municípios devem ser o território de difusáo e usufruto dos recursos e implantaçōes do Projeto. Se as sedes de microrregióes ou sedes de municípios puderem oferecer espaços e infra-estruturas para a formaçáo e funcionamento de bancos de germoplasmas tanto mais garantido o sucesso das implantaçóes. Mesmo que fosse em nível de simples hortos-filiais, da categoria de bancos de mudas para reflorestamento de áreas críticas, a contribuição dos municípios para a dinâmica de implantaçáo, difusáo e acompanhamento pode ser considerada essencial $\mathbf{e}$ indispensável.

No nível de gerenciamento e avaliaçăo da somatória das implantações, é importante a criação de uma instituiçăo central, geradora de idéias e irradiadora de diretrizes, capaz de motivar os processos de implantação, exercer as interaçóes regionais necessárias e complementar a monitoração e o progresso do Projeto FLORAM, até onde for de seu alcance. Enquanto o gerenciamento e as açóes práticas, que necessariamente se fazem no espaço efetivo das glebas rurais, deverá ser exercido e dinamizado pelos órgáos federais e estaduais, em vinculaçáo direta com os recursos técnicos dos municípios.

Os responsáveis pelo Projeto FLORAM têm plena consciência da necessidade de aperfeiçoar a "ponte" entre a pesquisa básica e a extensão agrícola, sem o que qualquer programa agrário revitalizador pode funcionar. No âmbito do FLORAM, o velho problema surge com igual intensidade de entraves: nada de prático poderá ser feito caso inexista a capacidade e vontade técnica e científica de dinamizar os múltiplos projetos de florestamento e/ou reflorestamento. Há que 
se envolver mais diretamente nas diretrizes e fundamentos do Projeto; fazer investidas no campo da Educaçáo Rural, e avaliar as potencialidades internas de grandes glebas. Enfim, aplicar a Agronomia à diferenciação de atividades intraglebas, dosando espaços para silvicultura. Introduzir espécies. Reafeiçoar terrenos degradados e drenagens parcialmente desperenizadas. Sem prejuízo para a manutenção de atividades agrárias ou agropecuárias. Isto, para pequenas ou médias propriedades das regiōes serranas empobrecidas do Brasil de Sudeste e Leste. Com relaçáo às grandes propriedades do Brasil Central - selecionadas para um florestamento mais amplo e extensivo -, as disponibilidades espaciais sáo muito maiores: aí se pode reflorestar glebas no nível de $\mathbf{4 0}$, ou, no máximo, $45 \%$, diversificando o uso do núcleo restante através de atividades tradicionais (pecuária), inovaçóes agrícolas (produção de cereais, soja, arroz de sequeiro), e reservando-se espaços de até 15 ou $20 \%$ para unidades internas de preservação de bancos genéticos da natureza (cerrados e cerradóes de interflúvios, capóes de matas e florestas-galerias). Evidentemente, os que se vincularem ao projeto terão fazendas organizadas e participarăo do milagre de transformar latifúndios em grandes propriedades produtivas, social e economicamente úteis para a regiăo e o país.

As garantias desejadas para um bom andamento do Projeto dependem do nivel de conhecimento acumulado, honestidade e disposiçáo dos que váo implantar os subprojetos no "varejo". Para não falar da continuidade administrativa, recursos disponíveis e estratégias alternativas para correçăo de rotas operacionais.

\section{Papel indutor do IEA/USP}

Para efetivar um plano tăo amplo de reflorestamento, há que se induzir governantes, empresários esclarecidos, proprietários de terras (mesmo aquelas situadas em áreas incultas e degradadas), cientistas e técnicos, operariado agrícola e industrial, mestres e professores, para trabalhar na viabilização das implantaçóes de fitomassas nos diferentes espaços pré-selecionados, ou mesmo em outros que tenham vocação comprovada para tanto. Ninguém pretenderia que num país vinculado ao regime das propriedades privadas se pensasse num plano que deixasse de atentar para essa realidade básica. Pelo contrário, toda a estratégia do plano de reflorestamento deve conduzir para o campo da induçáo, em se considerando a estrutura fundiária regional e a possibilidade de encontrar aliados para a grande tarefa de dinamização regional, através de uma silvicultura combinada com melhoria da pecuária e da produtividade agrícola. 
Muitos empresários bem-sucedidos, no campo da silvicultura, teráo interesse em adquirir terras para reflorestamento nos espaços identificados pelo Plano. Será sempre um bom empreendimento adquirir glebas em áreas de terras incultas e de difícil manejo, situadas fora dos círculos de economicidade habituais. Mas será necessário exigir precauçóes mais cuidadosas no plano de manejo silvicultural, reservando-se áreas para preservaçáo dos ecossistemas representativos dos diferentes domínios da natureza regional, e dando continuidade parcial às atividades agrárias tradicionais da região.

A Universidade, pelo caráter multidisciplinar de sua ação e pelo forte comportamento social que impregna as idéias e propostas emergentes dos seus "campi", não pode deixar de alertar - com toda a ênfase, que seu compromisso social impóe - para o risco da concentraçáo de terras que um programa como este poderia acarretar. As consequências negativas seriam novas levas de "sem-terras a perambular pelas periferias faveladas das cidades e pelas bordas das reservas de florestas nativas, pressionando pelo parcelamento, para fins agrícolas, de áreas de alto interesse ecológico, que se transformariam em mais alguns espaços de sobrevivência precária e bolsóes de pobreza.

O modelo que o Projeto FLORAM vem de propor enfatiza o " florestamento" diferencial das propriedades pelos próprios donos atuais, evitando-se assim o caminho simplista de alienação aviltada de propriedades e $o$ conseqüente agravamento das desigualdades no campo social, que já causam tantos entraves ao processo de desenvolvimento da nação como um todo. O Plano é reformista, a seu modo, sem prejuízo de outros níveis de reformas.

Cabe à Universidade, poitanto, - através do melhor que ela possui, em termos de conhecimentos acumulados e propostas multidisciplinares -, ofertar parâmetros para um novo cenário de organizaçáo do espaço, em importantes áreas interiores do país. Transformar regióes inteiras por um novo padrão de reflorestamento poderá se constituir na valorização de terras incultas, complementarizaçáo da economia regional, e, sobretudo, na revalorizaçáo dos espaços críticos, altamente vulneráveis perante os fatores de degradaçáo, existentes nas terras da retaguarda Sudeste do Brasil.

\section{Taxas de ocupaçáo regional versus taxas de ocupação intraglebas}

Para garantir o sucesso de um plano de reflorestamento para um país de grandes dimensóes, porém dotado de uma complexa organizaçáo de 
... pretende-se, no ambiente do

IEA/USP, possibilitar 0 acesso a todos os documentos técnicose cientificos sobre reflorestamento no Brasil e na América Latina. espaços geográficos e sociais, a questão das taxas de ocupaçáo regionais em contraponto às taxas intraglebas adquire uma importância essencial. Trata-se de evitar o tamponamento de grandes espaços territoriais por florestas plantadas. Por todos os meios e estratégias, impedir a formaçáo de grandes e pouco diferenciados contínuos de eucaliptos, pinus ou qualquer outra espécie. Não interessa ao país um florestamento que implique a expulsão do homem rural ou no bloqueio de atividades agrárias (ou agropecuárias), por grandes espaços territoriais. Nem tampouco é aconselhável a constituiçấo de cenários homogêneos - congelados e quase irreversíveis - por grande espaço de tempo, capazes de impedir a introdução de outras atividades ou o encontro de novas vocaçóes, igualmente importantes, em se considerando o futuro.

Visando corrigir, de saída, tais distorçôes, introduzimos no Projeto FLORAM dois conceitos limitantes em relaçáo aos máximos toleráveis para o reflorestamento/florestamento das áreas pré-selecionadas. Nesse sentido, diferenciamos preliminarmente o conceito de taxa de ocupação regional em relação à taxa de ocupaçáo intragleba (sítios, fazendas, latifúndios). Por taxa de ocupação regional entendemos o máximo percentual tolerável ou aconselhável de florestas a serem introduzidas em uma determinada área; sem prejuízo para as atividades rurais atuais ou futuras e, sob o pressuposto de estabelecer subespaços geoecológicos para refúgios de flora e fauna originais, bancos genéticos da natureza e unidades de conservaçâo. $O$ conceito de taxa de reflorestamento intragleba envolve, por sua vez, outras variáveis, incluindo-se a avaliação da economicidade do empreendimento a nível financeiro e social, assim como projetos dirigidos caso a caso, modelos geométricos e funcionais de organizaçáo dos espaços internos da gleba, cenário global das vizinhanças, entre outros. Nesse sentido, a taxa de ocupaçáo intragleba varia segundo a tipologia do reflorestamento preconizado, podendo envolver taxas de ocupaçăo ligeiramente superiores àquelas previstas para a regiáo, vista em seu todo. Nas áreas de reflorestamento industrial, previamente selecionadas no interior do Brasil extra-amazônico, as taxas de ocupaçáo regionais ideais giram em torno de 25 a 30\%. No entanto, pode-se ampliar para níveis de 30 a $45 \%$ a taxa de ocupação máxima intragleba; exigindo-se que os espaços não-florestados incluam outras atividades rurais, socialmente rentáveis, e a preservaçăo de no mínimo $20 \%$ de subespaços internos de preservação (florestas-galerias, cabeceiras de drenagem, nascentes ou "olhos-d'água", veredas, algumas cimeiras ou interflúvios passíveis de serem congelados para bancos de germoplasmas ou refúgios de flora e fauna).

Sem a consideraçăo de tais pressupostos, o Projeto FLORAM náo 
deverá ser iniciado, em hipótese alguma. Sendo que, evidentemente, para garantir a obediência a essas posturas, torna-se necessário um planejamento das açóes de monitoração, gerenciamento e manejo, na base de técnicos e administradores honestos e preparados, sob a batuta de instituiçōes públicas e assessores não-governamentais, esclarecidos e dignos de confiança. Sem o que, $o$ aval da comunidade científica náo pode será dado ao Projeto.

\section{Manutenção da biodiversidade: a , responsabilidade brasileira}

Neste fim de século, nenhum país herdou tanta responsabilidade face à preservaçáo do mundo vivo da Biosfera quanto ó Brasil. É certo que a conservação da biodiversidade dos mares e oceanos é uma obrigação de todas as naçōes do mundo. Mas, a preservaçăo dos grandes estoques de componentes bióticos - em condiçóes integradas existentes nas terras emersas dotadas de climas quentes e úmidos, geradores de extensivas biodiversidades - tornou-se uma tarefa predominantemente brasileira.

Pessoas e grupos esclarecidos do mundo inteiro, interessados na grande missáo de pensar o destino do planeta Terra, sentem-se muito à vontade para alertar $\mathrm{e}$ pressionar brasileiros $\mathrm{e}$ autoridades brasileiras para a elaboração de uma correta política de preservaçáo das biodiversidades existentes em cada domínio da natureza no Brasil. Entendemos a preocupaçăo e não discutimos a sinceridade das estratégias de preservação das biodiversidades tal como nos tem sido proposto. Entretanto, queremos reafirmar que, da Amazônia ao Rio Grande do Sul, a responsabilidade pela preservação será sempre nossa. A luta não é fácil: temos que lutar em diversas frentes, contra modelos e indivíduos insensíveis ao ecocídio, ao genocídio e ao etnocídio. $\mathrm{E}$, até mesmo contra os detentores das verdades genéricas, porém impotentes para formular estratégias, somar forças ou se expor a debates públicos sérios e aprofundados. $\mathrm{Na}$ ânsia de forjar legislaçóes, redigir plataformas, listar pequenas multas, fazer propaganda de projetos pontuais, ou simplesmente obter recursos para pesquisas em relação às quais não dispóe de competente massa crítica, instalou-se a balbúrdia generalizada, a despeito da abnegaçáo e do espírito missionário de muitos. E tudo continua a acontecer, numa sincronia de difícil visualizaçáo, desde Roraima ao Sudoeste do Rio Grande do Sul, desde as praias e grandes cidades de Leste, até os pantanais do extremo Oeste. Campeia o imediatismo. Rotulam-se os planos dos vizinhos, de tecnocratas, enquanto se está de máos vazias, em termos de planos e açóes abrangentes. Enquanto se deixa acontecer, um pouco 
ou muito de tudo, no terreno das predações, poluição e queima de recursos naturais, ao longo de um território de dimensóes continentais.

O balanço em relaçăo às biodiversidades regionais é estarrecedor, não apenas pela somatória da devastação ao longo dos séculos, mas sobretudo pelo ritmo da destruiçáo nos últimos trinta anos (1960-1990). As áreas mais predadas, por razóes óbvias, situam-se no Brasil atlântico, por onde se iniciou o povoamento através dos principais ciclos agrários históricos e onde se desenvolveram as principais redes urbanas e, por muito tempo, se retirou lenha e carvăo. Além do que, foram áreas que asilaram os principais parques $e$ distritos industriais do país, incluindo tecnologias obsoletas e altamente agressivas para o meio ambiente: indústrias químicas $\mathrm{e}$ petroquímicas, indústrias de cimento, indústrias de defensivos agrícolas, refinarias de petróleo, termoelétricas, entre outras. Ainda que não se possa comparar as taxas de liberaçăo de gás carbônico dessas indústrias quando comparadas com a somatória de emissóes das áreas industriais do Primeiro Mundo.

Freidel (1977) condensou as questóes básicas sobre as relaçóes entre as plantas verdes e o ciclo do gás carbônico na atmosfera, incluindo consideraçōes sobre o uso dos combustíveis fósseis e sua participaçáo na liberaçăo de $\mathrm{CO} 2$. Em uma determinada passagem de sua análise, o autor tece consideraçóes cautelosas sobre o grande interesse dos programas de reflorestamento para evitar os riscos da "supercarboxilação".

O termo biodiversidade, apesar de implícito em todas as consideraçóes sobre o mundo vivo que constitui o atributo máximo da originalidade do planeta Terra, foi introduzido muito recentemente na linguagem corrente dos ecologistas e ambientalistas. Poucos dicionários ou ensaios bibliográficos puderam incorporá-lo aos termos usuais das ciências da vida, até o fím da década de 80. Mesmo porque, a expressáo alusiva à diversidade da vida existente em cada zona, domínio ou região da natureza terrestre, foi estabelecida e divulgada por ecologistas militantes, interessados na grande tarefa da preservação integrada dos grandes agrupamentos de vida silvestre, que resistiram às atividades predatórias seculares do homem. Expressóes tais como biodiversidade, bancos de germoplasmas e bancos genéticos da natureza são de introdução recente, internalizando preocupaçóes estratégicas relativas ao futuro do planeta. Pensar nas biodiversidades que existiam e, sobretudo, naquelas que sobreviveram, é uma obrigação permanente daqueles que refletem sobre o futuro do planeta Terra, a diferentes níveis de profundidade de tempos. Os economistas 
pensam nas tendências evolutivas dos cenários econômicos no nível de alguns anos ou em épocas de rupturas ocasionadas por mudanças de governantes ou interferência de fatores extrógenos, ligados a tempos relativamente curtos. Os ecologistas têm, no mínimo, preocupaçōes mais dilatadas de tempo, pensando na permanência e equilíbrio do mundo biológico, a partir da escala de tempo dos últimos períodos geológicos, da flutuante climatologia e biogeografia dos tempos quaternários, que envolvem milhares ou dezenas de milhares de anos.

É verdade que os países do Primeiro Mundo pouco ou nada puderam fazer para preservar a biodiversidade de suas ecozonas ou domínios biogeográficos. Pelo contrário, nos últimos tempos da revoluçảo industrial deixaram acontecer de tudo: eliminaçăo da biodiversidade, poluiçáo do ar, poluição dos litorais, poluição dos rios e águas costeiras, formação de maciços florestais homogêneos, agricultura baseada em uns poucos produtos de valor alimentício ou industrial, pecuária baseada em pouquíssimos animais domésticos. E, agora, muitas vozes tentam apelar para a clarividência das lideranças culturais do Terceiro Mundo, no sentido de preservar a exuberante biodiversidade dos Trópicos úmidos. Nada a opor aos estímulos ou pressões que venham de fora: a inteligência do problema tem que ser conduzida por nós próprios brasileiros, harmonizando antagonismos, dosando programas e encontrando soluçóes que nos permitam libertar dos grilhốes das dívidas contraídas por terceiros em nome da sociedade brasileira. $\mathrm{E}$, em circunstâncias que nos permitam realizar conquistas no campo da modernidade sem destruiçăo das biodiversidades herdadas, ou queima concessiva dos recursos naturais básicos. Daí o apelo ao conhecimento dos tipos de espaços que compöem os países subdesenvolvidos de grande extensão territorial, visando encontrar propostas ecodesenvolvimentistas diferenciadas $e$ viáveis, para cada região do país, no nível de seus atributos físicos e ecológicos, infra-estruturação regional, conjunturas sócio-econômicas e ambientais, e exigências sociais básicas.

As ponderaçōes de $\mathrm{H}$. Friedel exigem algumas reflexóes sobre as estratégias para se conseguir um razoável seqüestro do gás carbônico liberado para a atmosfera. A favor da implantaçáo maciça de plantas verdes, de crescimento rápido, $\mathrm{e}$ da reintroduçáo de espécies nativas em áreas e faixas de espaços predados, onde sem qualquer retorno econômico ou prejuízo maior para atividades agrícolas ou de pecuária se possa reflorestar. Qualquer política bem conduzida de reflorestamento tem que levar em conta um conjunto de diretrizes para cada tipo de espaço do país para o qual ela se destina. E, mais do que isso, tem que prever o espaço de tempo para a implantação dos programas de florestamento/reflorestamento, a avaliaçáo da 
continuidade administrativa, a força de exigência e perseverança das comunidades técnico-científicas e elites culturais envolvidas na política ambiental, no nível do planeta e da nação. Não há como se basear tāo-somente na tecnologia silvicultural, nem tampouco minimizar os conhecimentos e técnicas acumuladas nos meios acadêmicos e empresariais. Há que colher espaços por múltiplos critérios de inclusão ou exclusáo; conhecer o mosaico de solos e suas potencialidades e limitaçōes para introdução e/ou reintrodução de espécies; avaliar e reavaliar as razóes do sucesso ou insucesso de iniciativas de florestamento feitas no passado; produzir novos modelos para fazendas obrigatoriamente mistas, envolvendo talhōes de florestas produtivas, espaços de preservaçăo obrigatória em diferentes níveis e compartimentos da topografia; além de alguns subespaços para a manutenção de atividades tradicionais melhoradas no interior das glebas revitalizadas pela silvicultura. Năo basta manter uma boa taxa de biodiversidade nos fundos e flancos baixos dos vales, reservando-se todas as vertentes e interflúvios para florestamentos extensivos à custa de espécies de crescimento rápido. A reconquista e reexpansão da biodiversidade deve ser um processo diferencial a ser conquistado em todos os tipos e tamanhos de gleba, por diferentes estratégias e procedimentos, sem que para tanto seja necessário reafeiçoar grandes espaços com florestas em detrimento de agroecossistemas ou de sistemas agrossilvopastoris. Esse é o dilema a ser resolvido em programas diferenciados $e$ inteligentes de

reflorestamento/florestamento, através de uma consciente avaliaçáo das necessidades de melhoria das condiçóes ambientais da Atmosfera, assim como dos espaços territoriais urbanos, rurais e silvestres de todos os países do mundo. As naçōes possuidoras de maior tamanho de espaços e disponibilidades de terra para múltiplo reflorestamento têm a obrigação histórica de engendrar e implantar políticas de proteção das biodiversidades remanescentes, ao mesmo tempo em que trabalham para o seqüestro do gás carbônico liberado pela somatória das açóes poluidoras das indústrias, da queima de combustíveis fósseis e das grandes queimadas aplicadas criminosamente às florestas nativas de alguns poucos e privilegiados países, como é o caso do Brasil.

O Projeto FLORAM é um vasto e articulado programa, de amplitude nacional, para a melhoria do ambiente global; garantia da preservação das biodiversidades remanescentes; reimplantaçăo de biodiversidade em áreas fortemente predadas; atenuaçáo das pressóes predatórias sobre a Amazônia; e implantação progressiva de florestas produtivas, sob taxas regionais limitadas, e sob modelos rurais revitalizantes e de abrangente interesse social. Através de sua preocupaçáo com a revitalizaçáo social e econômica de espaços mais carentes, e de correta organizaçáo dos grandes espaços constituídos por planaltos interiores 
subutilizados, o Projeto poderá influir positivamente na conquista de novos cenários civilizatórios para o país.

\section{Planos, estratégias e diretrizes para preservar biodiversidades regionais}

Na elaboraçáo do Projeto FLORAM, houve preocupaçóes

fundamentais, referentes à preservação das biodiversidades: 1 . ao exemplo do fomento para florestas produtivas, induzir uma nova organizaçáo dos espaços internos das glebas, a fim de prever um razoável prosseguimento das atividades rurais tradicionais de cada regiāo, preservar todos os fundos de vales e baixas vertentes, mas, sobretudo, incluindo refúgios de flora $\mathrm{e}$ fauna $\mathrm{em}$ uma ou mais áreas interfluviais; 2 . em funçáo desta mesma postura, contribuir para transformar os latifúndios de chapadóes interiores em legítimas fazendas, econômica e socialmente vivas e rentáveis (independentemente da própria rentabilidade da madeira); 3 . deixar em aberto a possibilidade de relocaçáo de algumas unidades industriais - nos próximos dez anos - para locais dotados de uma certa centralidade (ou em áreas contíguas) às novas regióes de florestas produtivas, bem-sucedidas; fazer exigências especiais para o registro e controle dos setores intraglebas dotados da biodiversidade regional (em fundos de vales, vertentes ou interflúvios).

Os limites de taxas de ocupação intraglebas foram estabelecidos a fim de reservar pouco mais da metade do espaço total de cada gleba para o desenvolvimento de atividades rurais tradicionais (passíveis de serem melhoradas) e um bom espaço desse total para preservação de espaços naturais integrados, na forma de redutos obrigatórios de fauna e flora. Dentro dessas premissas, o cenário previsto para as futuras fazendas a serem estabelecidas em áreas de chapadóes revestidos por cerrados dotadas de baixa densidade hidrográfica - envolverá a presença de maciços florestais até o nível de 40 a $45 \%$ do espaço total da gleba, 25 a $30 \%$ para a preservaçáo de ecossistemas peculiares da região (cerrados interfluviais e de vertentes, matas-galerias e veredas), e 25 a $30 \%$ de espaços para atividades agrícolas ou pastoris, em setores de jusante em relação à posição das cabeceiras de drenagem. Uma fazenda assim organizada, nos chapadóes do noroeste de Minas Gerais, ou nos chapadōes ocidentais da Bahia (Urucuia), ou regiōes similares, terá sempre a oportunidade de ser rentável, produzir empregos e realizar um efetivo desenvolvimento regional. Existem pressupostos, de detalhe, tăo importantes quanto a divisão interna dos espaços da gleba. Por exemplo, deve-se fazer todos os esforços possíveis para evitar a devastação das matas-galerias (Brasil Central) ou faixa diferenciada da vegetação de beira-rio (Amazônia). Entretanto, para tornar possível a 
chegada do gado até bebedouros naturais, espaçados entre si, há que adotar alternância de desmate, de espaço a espaço, em posição assimétrica, nas matas beiradeiras. Desta forma, através de um esquema de "baionetas" ou "virabrequins", aplicado aos desmates estritamente necessários, possibilita-se o acesso à água, evitando-se, porém desmatamentos excessivos e desnecessários. Algumas dessas proposiçóes podem ser indicadas para o reflorestamento misto, mais contido e miniaturizado, em pequenas e médias propriedades de áreas excessivamente depredadas do Brasil Tropical Atlântico.

Nas estratégias organizadas para proteger as grandes áreas florestadas da Amazônia, o Projeto FLORAM prevê um esforço a médio prazo, para reflorestamentos igualmente híbridos, no cinturāo das terras periamazônicas (norte de Mato Grosso, Rondônia, sul do Pará). Dadas as condiçóes da entrada de energia solar na área e o quantum de precipitaçóes anuais que regam ou espaços regionais, os programas de florestamento e reflorestamento encontram um grande auxílio da própria natureza para viabilizar os processos de introduçăo, reintrodução e reenriquecimento de espécies arbóreas.

Na elaboração do Projeto FLORAM, houve preocupaçס̄es fundamentais, referentes a preservaçāo das biodiversidades...

As limitaçōes ecológicas existentes na Amazônia para agricultura - de há muito sublinhada por cientistas os mais categorizados incentivam-nos a preservá-la ao máximo da área possível e pelo maior espaço de tempo imaginável, independentemente de uma permanente busca e experimentaçáo de estratégias ecodesenvolvimentistas. Tais condicionamentos acabam por fazer da Amazônia a maior e mais densa reserva de biodiversidade da face da Terra. A despeito de toda uma somatória recente de processos predatórios, $90 \%$ do continuum florestal amazônico permanece em razoável estágio de preservaçáo. Uma imensa maioria de brasileiros conscientes defende a preservaçáo da Amazônia e a adoçáo de padróes ecodesenvolvimentistas regionalizados para usufruto das populações regionais e integração econômica e social com o restante do país. Previsão de instalaçăo e multiplicação de reservas extrativistas; cuidados inflexíveis para as reservas indígenas, desdobramento de unidades de preservação; busca de padróes agrossilviculturais; repúdio a qualquer atividade poluidora que afete a qualidade das águas com implicaçóes negativas para a ichitiofauna; crítica permanente a represamento de rios no coraçáo das selvas; contensão dos apetites irrefreáveis dos madeireiros. Dessa forma, se náo houver nenhum acidente político de percurso, a Amazônia continuará sendo a grande reserva de biodiversidade no planeta. Uma imensa biodiversidade nas florestas de terra firme. Biodiversidades específicas nas planícies, envolvendo florestas beiradeiras, igapós, várzeas, campinas, campinaranas, campos submersíveis. E uma particularmente importante biodiversidade nas 
águas continentais, nos rios, igarapés, lagos de várzeas, lagos de terra firme e estuários regionais.

Se, para a Amazônia, sobreexiste a possibilidade da preservação de uma extraordinária biomassa de ambientes tropicais, na área das antigas matas atlânticas, a situação é calamitosa. Por áreas imensas, perdeu-se biomassa por mais de $\mathbf{9 0 \%}$ dos antigos espaços florestados; e, com isso, lá se foram as biodiversidades que marcavam áreas litorâneas, sublitorâneas e planálticas da regiāo. Poucas pessoas podem avaliar o que foi a perda generalizada das biodiversidades, ao longo do Brasil Tropical atlântico. As matas, ditas atlânticas, que se iniciavam no Rio Grande do Norte (fronteira com a Paraíba) e que se estendiam ininterruptamente até ao sul de Santa Catarina, com vastas penetraçóes nos planaltos serranos do Brasil de Sudeste, possuíam combinaçóes de biodiversidades de Norte para Sul e das planícies e piemontes de serras e escarpas para os planaltos interiores. Incluíam variaçóes de composição devido à sua extensão azonal, zonação altitudinal, e história vegetacional quaternária. Até certo ponto, as variaçóes de biodiversidade ao longo das matas atlânticas do Brasil podem ter sido presumivelmente maiores do que aquelas existentes ao longo de imensas terras baixas da Amazônia. A extensão e a intensidade da devastaçáo respondem por imensa perda da diversidade biótica, envolvendo o desaparecimento sobretudo de espécies e combinaçóes de espécies, a nível fitossociológico.

Face a essa destruiçăo generalizada dos patrimônios genéticos das matas attânticas, é possível impor condiçŏes legais para preservaçăo integral de todos os pequenos remanescentes correspondentes a matas de fazendas, matas de escarpas tropicais e coberturas de maciços íngremes das regióes serranas do Leste e Sudeste do Brasil. No interior das fazendas do domínio tropical atlântico - desde a zona da mata nordestina ate Santa Catarina -, os remanescentes de matas ou capoeiróes são bem inferiores a $20 \%$, fato que possibilita a aplicaçáo de leis protetoras diretas e rígidas para uma definitiva preservação dos reduzidos remanescentes. Para tanto, bastaria a energia cultural e administrativa dos órgáos competentes, sob a batuta de pessoas esclarecidas $e$ independentes. Ao que se somariam as diretrizes do Projeto FLORAM para a reintroduçăo de espécies e reafeiçoamento diferenciado da cobertura vegetal das propriedades rurais existentes no domínio dos morros.

Evidentemente, além de políticas especiais para a Amazônia e o Brasil Tropical Atlântico, todos os outros domínios de natureza do país solicitam posturas e diretrizes específicas para a preservação de bancos de germoplasma e mosaicos de ecossistemas em convivência natural. 
Incluem-se, no caso, programas de proteçáo de amostras e combinaçóes de ecossistemas peculiares no domínio dos cerrados, no domínio dos sertóes secos, no domínio dos planaltos de araucárias, como também no domínio das pradarias mistas penetradas por florestas galerias do Rio Grande do Sul (estas últimas atingidas profundamente pela desmesurada $e$ incontrolada expansáo dos arrozais). Sem grande quebra da economicidade, o Projeto FLORAM inclui propostas adequadas para conter a biodiversidade característica de todas essas áreas, consideradas heranças fundamentais de nossos patrimônios bióticos.

\section{Projeto FLORAM: visão perspectiva do desafio}

Ao embrião do Projeto - que vem sendo desenvolvido no ambiente do Instituto de Estudos Avançados da USP por um eclético grupo de trabalho - devem se agregar contribuiçóes progressivamente mais detalhadas, distribuídas por um leque de estudos técnicos e operacionais, considerados absolutamente indispensáveis. Caberá ào Grupo de Trabalho do IEA/USP fazer ou providenciar a elaboração de tais contribuiçōes, centradas nas técnicas de: avaliafaño de riscos do Projeto, visto como um todo; organizafá̃o de estratégias para captafáo de recursos, em diferentes fontes, para viabilizar o Projeto; propostas para a institucionalizafáo do Projeto; avaliafão crítica do antigo sistema de subsídios para reflorestamento, tendo em vista as mudanças fundamentais na estrutura, composiçáo de forças e funcionalidade do Projeto; previsũo de impactos econdmicos c avaliação das metas sócio-econômicas; prognósticos dos cenários a serem obtidos nas diferentes glebas selecionadas; estudo dos pontos ou núcleos de difusä́, considerados estratégicos para a implantaçáo progressiva do Projeto, em diferentes áreas; e, por fim, delineamento da organizaçá de um sistema confidpel e dindmico de sensoreamento remoto vinculado ì monitorafáo e ao gerenciamento espacial das florestas em implantação. Bastaria a listagem dos estudos, que, obrigatoriamente, deverão ser elaborados, para se ter uma idéia de quanto ainda será necessário realizar e, sobretudo, da diversidade dos estudos e pesquisas multidisciplinares que deverão ser feitos em regime de urgência. Ao ensejo da realizaçáo dos diferentes estudos e pesquisas, pretende-se, no ambiente do IEA/USP, possibilitar $O$ acesso a todos os documentos técnicos e científicos sobre reflorestamenic no Brasil e na América Latina, para fins de consulta permanente aberta a todos os interessados. Seráo de igual importância, nesse sentido, os documentos monográficos e planos técnicos, quanto às documentaçáo cartográfica e de sensores remotos, assim como os estudos feitos para a recomposiçăo florestal de áreas críticas, tais como o caso de Cubatăo. 
Temos consciência de que nem todas as áreas selecionadas no Plano de Reflorestamento - elaborado no Instituto de Estudos Avançados da USP, por um grupo de especialistas - são conhecidas por todos os grupos de empresários, ambientalistas e políticos. Dessa forma, em face da grandiosidade e dilatação dos espaços envolvidos, haverá muita deficiência de informação e compreensão. Ocorrerão certamente avaliaçōes reducionistas ou indagaçóes simplórias. Muita repetiçăo da clássica pergunta: " mas terá que ser sempre um reflorestamento com essências nativas da região?". Será difícil tornar a explicar que para as áreas que náo possuíam verdadeiras florestas, como aquelas dos cerrados, ou das pradarias mistas do Extremo Sul, o reflorestamento é apenas uma grande empreitada de "florestamento" de espaços abertos, à custa de espécies alienígenas, fortemente adaptáveis às condiçōes climáticas e ecológicas regionais.

Nunca será fácil responder convincentemente às questóes da preferência dos clientes das classes mais abastadas: " $\mathrm{Se}$ eu posso comprar uma porta de mogno ou cerejeira, como vou dar preferència para uma esquadria de pinho ou eucalipto?" Um dia, a difusão dos conhecimentos sobre o tratamento de madeiras menos nobres certamente possibilitará respostas. $O$ aumento da consciência sobre a necessidade de preservação da biosfera também poderá ser um argumento para minorar o uso abusivo de madeiras de lei. E, por último, o aprimoramento da exploração auto-sustentada poderá contribuir para a solução dessa dolorosa e pragmática interrogaçáo.

Ou, mais difícil ainda será ter a tranqüilidade suficiente para argumentar que, para garantir uma compensaçáo para a grande liberação de Carbono havida para a Atmosfera, algum país privilegiado em espaços improdutivos deva ampliar biomassas florestais, em volume $\mathrm{e}$ área suficientes para minimizar os efeitos negativos provocados por queimadas, desmatamentos inconsequientes $\mathbf{e}$ processos industriais agressivos. Caberá, aliás, ao Brasil - caso se adote um plano maciço de reflorestamento - rever a pressão crítica dos países do Primeiro Mundo, forçando-os a participar de um esforço coletivo de atenuação dos processos agressivos que ameaçam a sobrevivência da Biosfera.

Bibliografia

AB'SABER, Aziz Nacib

1966 - Dominio dos " mares de morros " no Brasil. - Instituto de Geografia-USP, Geomorfologia n.2, São Paulo.
1971 - A organizafáo natural das paisagens inter e subtropicais brasileiras. - In: III Simpósio sobre o Cerrado, Ed. da USP e Ed. E. Blucher Lrda., pp. 1-14, São Paulo. 
1974 - O domínio monfoclimatico semi- ALMEIDA, Sérgio Alberto de Oliveira drido das cantingas brasileiras. Geomorfologia n.43, IGEOGUSP, Săo Paulo.

1977 - O cardter diferencial das dirctrizes para uso e preservafato da natureza, a ntpel regional, no Brasil. - (Sinopse) Geogr. e Planejamento n.30, pp. 9-26, IGEOGUSP, São Paulo.

1981 - Dominios morfoclimaticos atuaise queterndrios na regiato dos cerrados. - Graton \& Intracratan n. 14, IBILCE-UNESP, São José do Rio Preto, SP.

1984 - Ecoswistamas Continentais. - In: "Relatório da Qualidade Meio Ambiente" (RQMA) SEMA, Brasilia.

1986 - Geomorfologia da Reginto (Caraj(s). - In: "Carajás: Desafio Políicico, Ecologia e Desenvolvimento" (J.M. Gonçalves de Almeida Jr., Org.), pp. 88-124. CNPq e Brasiliense, São Paulo.

1987 - Genese de wana nova regiáo sideruirgica: acertos e distorfótes de origem, na frivea Carajas/Sa Luiz. - Desenvolvimento n.22 (jul./dez. 1987), Pp. 3-15, IDESP, Belém, Pará.

AB'SABER, A. N., CHACEL, F. M. e TSUKUMO, N. M. J.

\section{5 - Tratamento paisughstico da Usina de Paraibuna e Barragem de Pa- raitinga. Geografia e Planeja- mento n. 17, IGEOG-USP, Săo Paulo.}

ALMEIDA, D.G. de

1946 - Madciras imunes ou muito resistentes ao cupiom. - Revista Florestal, vol.5, n.2, pp. 13-23.

\footnotetext{
ALMEIDA, D. G. de e COSTA, J. R. da 1956 - Madoiras do Brasil. - Serv. de Econ. Rural. Ministério da Agricultura, Rio de Janeiro.
} Programa de Monitoramento da In: "Simpósio sobre a Caatinga e sua Exploraçăo Racional", Pp. 271-279, Univ. Est. de Feira de Santana, EMBRAPA, Brasilia, DF.

ARANHA PEREIRA, J. e MANIERE, G. 1949 - Madciras do Brasil. - Anuário Brasileiro de Economia Florestal, vol.2, pp. 285-351, Rio de Janeiro.

ARKCOLL, David B.

1979 - Uma apaliaguto das opfóes agrossilviculturais para a Amazbria. - Anais do Simpósio sobre Ciências Básicas e Aplicadas. Publ. da ACIESP, n.19, pp. 101-111, São Paulo.

ASSIS RIBEIRO, Paulo de

1975 - Os recursos naturais e o planejamento. - SUPREN. IBGE, Rio de Janeiro.

AUBREVILLE, $A$.

1961 - Étude Ecologique des Principales Formations Forestitres du Brtsil. - Centre Techn. de Foret Trop., Paris.

AZEVEDO, M.L. e PHILLIPP

1979 - Bibliografia de encalipto: autores - publicapóes nacionais. - IPT (Publ.1148). Inst. de Pesqs. Teens., São Paulo.

BASTOS, A. de $M$.

1951 - O mogno brasilciro. - Anuário Brasileiro de Economia Florestal, n.4, pp. 136-141.

BRISCOE, $C$.

1979 - Agroforesteria en Jari Florestales y Agropecudria, Brasil. actus Taller Sistemas Agroforestales en America Latina. Turrialba, Costa Rica, Centro Agron. Tropic. Invests. y Enseñ. LATTE. Turrialba.

BRONBANI, E. J. e SILVA, L. C. da

1983 - Arborizaguto de agudes e barragens. - DRNR (Secretaria da Agricultura - Est. Rio G. do Sul), Porto Alegre. 
BORGONOVI, M. (e outros)

1967 - Cobertuora Vegetal do Eserado de Siso Paulo, II - Lepartamento por Fotointerpretaguto das Areas Cobertas com Floresta - Natuoral o Reflorestamento. - Bragantia, ano 26, n.6, Pp. 93-117, Campinas, SP.

CABRERA, A. L. e WILLINK, A.

1973 - Biogeegrafia de Ambrica Lativa. - OBA - Depto. de Assuntos Cientficos. Washington D.C.

CARLETON RAY, G.

1988 - Ecologiecal Diversity in Constal Zomes and Oceans. - In: "Biodiversity" (Wilson, E.O.1988), pp. 36-50, National Acad. Press., Washington D.C.

CARVALHAL, C. $M$.

1979 - Gomenatidades solve a fiseagho e conselidiagrio de dunas come vegetafio. - AGROS, vol.14, n.2, Pp. 55-66, Peloms.

CAVALCANTE, M. S., IELO, P. K. Y. e OLIVEIRA, A.M. F.

1984 - Bibliogmafin brasilaira am preservingrio de madeiras. - IPT (publ.15/2). Inst. de Pesgs. Tecns., Săo Paulo.

\section{CHARBONNEAU, J. P. (e outros)}

1979 - Enciclopertia de Ecologia. Conclusio de R. Dumont. Pref́acio de M.G. Ferri. Superv. TÉnica de A. Lamberti., Edit. Pedag. Ltda. e EDUSP, S3o Paulo.

\section{CENIRE NATIONAL DE LA RECHIER- CHE SCIENTIFIQUE \\ 1971 - La Regionalisertion de l'appes an Brtil. - CEDEC/CNRS, Bor- deaur/Talence.}

\section{CENTRO DE PLANEJAMENTO DA} BAHIA

1978 - Atlas climentoligico do Estado da Babia. O Clima e a organdizagulo do appago greogndfico. - (Dir. de C.A. de Figueiredo Monteiro). FAO - Commitee on Forest Development Documento-Sintese. CBP in the Tropics

Secr. de Planej. Ciência e Tecnol., Salvador.
1980 - Potencial de utilizageto do AllimSaro Franciseo. - Diagnóstico. CPB - Secr. de Planej. Ciência e Teenol., Salvador.

1980 - Mrepa geomorfologico do Esendo daBabia.-Escala: 1:1.000.000. Strie Recursos Naturais, n.3, $\mathrm{CPB}_{\text {, Secr. de Planej. Ciencia e }}$ Tecnol., Salvador.

\section{CIANCIULLI, P. L.}

1959 - A introduplio e acliomageio do Pimus Ellititi c outras Confficons no Eurdo de Siro Pardo. - Anuário Brasileiro de Economia Floresthl, n.11, pp. 66-89.

CORDEIRO, C. de A. e SOARES, L. de C.

1977 - A evesto nes solos arenoses da Regivo Sudesse do Rio Grande do Sul. - Revista Brasileira de Geografia (IBGE), ano 39, n.4, Pp. 82-149.

DIAS, Sérgio da Fonseca

1988 - Convidenagies sobre legislagio florestal e sur epplicagus de Amazednia: caso particular do carrito vegetul parn sidorometaliagia. Para Desenvolvimento, n. 24 (jul./dez. de 1988), Pp. 50-54, IDESP-Belém, Pará.

EITEN, George

1973 - An outline of the regetrion of South Amarica. - Symp. Intern.

ERWD, T. L.

1983 - Bectles and Otber Insects of Tropical Forast Comopies at Mesumens, Bracel. - In: "Tropical Rain Forest: Boology and management" (Sutton).

1988 - The Tropical Forest Canopy: The Hearth of Biotic Diversity. In: - Biodiversity" (Wilson,E.O. 1988), Pp.123-129. National Acad. Press., Washington.

1985 - Tropical Forestry Action Plan. FAO. Roma. Primat. Soc. 
FAO - IBRD - WRI - UNDP

1987 - The Tropical Forestry. Action Plan. - FAO (e outros). Roma, Italia,(em forma de Cartilha).

FAO - Food and Agriculture Organization of the United Nations

1988 - Forestry Action Plan for Latin America and the Caribbean. Executive Summary, FAOONU, ROMA.

FEARNSIDE, Philip $M$.

1985 - Brazil 's Amazon Forest and the Global Carbon Problem. - Interciência, vol. 10, n.4 (jul./agosto de 1985), pp.179186, (Contém bibliografia sobre o problema do Carbono Global).

1986 - Distribuigato de Solos Pobres na Colonizagato de Rondonia. Ciência Hoje, vol.6, n.33, Pp 74-78, SBPC.

FITTER, $R$.

1986 - Wildlife for Man. How and Why We Should Conserve Our Species. - Collins, London.

FONSECA Filho, C. de A.

1959 - Eschaias para reflorestamento e arborizagalo. - Bol. de Agricultura, vol.8, ns. 5-6, pp. 15-28, e Anais da Soc. Bot. do Brasil - XI Reuniāo Anual, I vol..pp. 93-111 (1962), Belo Horizonte.

FREIRE, L. C. (e outros)

1982 - Alguns aspectos econbmicos sobre a implantapato c utilizapto de capion buffel om drea de cantinga. CPATSA/EMBRAPA. Circ. Teen. n.9, Petrolina, PE.

FREITAS, A. R. e CHIMELO, J. P. 1984 - Utilizafato de inadiras amazbnicas para a produsfá de dommentes para o Projeto Ferro - Carajds. - IPT (Publ. 1487). Inst. de Pesqs. Tecns., Säo Paulo.
FRIEDEL, $\mathrm{H}$.

1979 - Asgrandes leis da Biosfira. - In: Charbonneau, J.P. (e outros). "Enciclopédia de Ecologia", Pp. 9-41, Edit. Pedag. e Univers. Ltda e EDUSP, São Paulo.

GLERUM, B. B. e SMIT, G.

1962 - Combined forestry/soil surpey, along road $B R-14$, from SAlo Miguel to Imperatriz. - FAO/ EPTA, rel. 1483. Roma.

GOLFARI, $\mathrm{H}$.

1980 - Zomeamento Ecologico para Reflorestamento da Area de Infiulencia da Serra dos Carajds. CVRD, Revista vol.1, n.2, pp. 3-18, Rio de Janeiro.

GOMES, A. M. B. C CARVALHO,

C. S. de e

1980 - Estudo de geomorfologia - Alegrese RS. - Instituto de Geociências, Publicação Avulsa, UFRS, Porto Alegre.

GONZAGA DE CAMPOS, Luiz Felipe

1912 - Mapa Florestal (Brasil). M.A.I. e C. - SGMB. Typ. da Diret. do Serviço de Estatística, Săo Paulo.

GRUPO DE PLANEJAMENTO ESTRATÉGICO FLORESTAL

1982 - Brasil Florestal, Ano 2000: diretrizes estrattgicas para o Setor Florestal Brasileiro. - Brasil Florestal, ano XII (abril/junho de 1982), pp. 7-33, Brasilia.

GUEDES, F.

1975 - Um descrto ameaca o pampa. Revista Geográfica Universal, n. 10, pp. 63-71, Rio de Janeiro.

GURGEL FILHO, C. A. e ALVARENGA, R. M.

1963 - As pindceas no reflorestamento do Estrado de Sto Paulo. - Atlas/Anexo do Boletim Técnico, n.17, Secr. da Agric., IF CPRN, Săo Paulo. 
GURGEL FILHO, C. A.

INSTTTUTO FLORESTAL - Coord: da

1964 - O comportamento florestal das Pesq. de Recs. Nats.

Coniferas. - Silvicultura 3, pp. 1975 - Atlas do Zoneamento Econónicic 129-188.

HEINSDIJK, D. e BASTOS, A. de M.

1963 - Inpentarios florestais na Amazbnia. - Setor de Inventários

Florestais - Min. da Agric., IPEF - ESALQjUSP

Bol. n.6, pp. 5-100, Rio de Janeiro.

HOEHNE, F. C.

1930 - Araucarilandia. - Secr. da Agric., Ind. e Com. do Estado de São Paulo.

HUECK, Kurt

1972 - Asflorestas da AmErica do Sul. (Trad. de "Die Walder Sudamerikas", Sturtgart, 1966, por Hans Reichardt), Ed. Polígono S.A., São Paulo. Florestal do Estado de São Paulo. - Atlas/Anexo do Bol. Téc., n.17, Secr. da Agric., IF/CPRN, Săo Paulo.

1987 - Revista IPEF - Número Especial sobre "Conservação dos Recursos Genéticos de Plantas" - Simpósio organ. por Paulo Y. Kageyama - Abril de 1986. IPEF-ESALQ/USP. Piracicaba, SP.

JORDAN, C. F. e RUSSEL, C. E.

1983 - Jari: productividad de las plantaciones y perdida de mutrientes debido al corte y la quoma. - Interciência, vol.8, n.6, pp. 294297.

HUECK, K. e SEIBERT, P.

KAYSER, Bernard

1972 - Vegetutions Karte pon Sudamerica. - Biogeography and Ecology in South America (Fittkau, E. J. e outros), vol.I, Pp. 54-81.

HUXIEY, A.

1984 - Green Inheritance. - Gaia Books Ltda., London.

1966 - Les divisions d'espaces gtographiques dans les pays sous-devellopts. - Annales de Geographie, ano LXXV, n.412 (nov./dez. de 1966), Paris, Publ. em trad. portug. In: Orientaçāo (IGEOG-USP), n.4, julho de 1969, pp. 25-30, São Paulo.

KERR, Warwick Estevam

1979 - A Amazbinia: sua floresta e sua ocupazáo. - Anais do Simpósio sobre Ciências Básicas e Aplicadas, Publ. ACIESP, n.19. pp. 85-100, São Paulo.

IBGE

1988 - Mapa da pegetafalo do Brasil. Escala 1:5.000.000, Secr. de Planej. e Coord. da Pres. da Repúbl., FIBGE/MA/ IBDF, Rio de Janeiro.

INDA, H. A. V. e BARBOSA, J. F.

1978 - Mapa geologico do Estado da Babia e Taxto axplicatipo para o mapa geologico do Estado da Babia. - Escala: 1:1.000.000. Secr. das Minas e Energia. Coord. da Prod. Mineral, Salvador.

KLEN, R. M.

1969 - Arpores natipas na Illba de Santa Catarina. - Insula, n.3, pp. 3-93.

KRUG, H. P.

1964 - Oplantio de Pinus em Säo Paulo. - Anuário Brasileiro de Economia Florestal, n.16, pp. 259-295.

LAMEGO, A. Ribeiro

1960 - Mapa geologico do Brasil. - Escala: 1:5.000.000, D. G. M. DNPM, Rio de Janeiro. 
LUCIETO, D. A.

1969 - Identificafão e utilidades das espécies do gênero "EUCALYPTUS" em São Leopoldo. Univ. do Vale do Rio dios Sinos.

MAACK, Reinhard

1947 - Breves noticias sobre a geologia dos Estados do Paraná e Santa Catarina. - Arquivos de Biologia e Tecnologia (PR), vol.2, PP. 63-154, Curitiba.

MAGALHĀES, L. M. S. e POSEY, D. A. 1987 - Reflorestamento indigena. Ciêricia Hoje, vol.6, n.31 (maio 1987), pp. 44-50, SBPC.

MAINIERE, Calvino

1958 - Madeiras do Brasil (II). Anuário Brasileiro de Economia Florestal, n.10, pp. 5-108.

MAINIERE, C. e CHIMELO, J. P.

1989 - Fichas de caracteristicas das $\mathrm{Ma}$ deiras Brasileiras. - 2 ed., IPT, Div. de Madeiras, São Paulo.

MAINIERE, Calvino e PEREIRA, J. A.

1965 - Madeiras do Brasil. - Anuário Brasileiro de Economia Florestal, n.17, pp. 135-416.

MALTBY, E.

1986 - Waterlogged Wealth. - International Institute for Environment and Development, London e Washington.

MARTIUS, EICHLER e URBAN. 1840 - 1906 - Flora Brasilienses. 40 vols.

MORS, W. B. e RIZZINI, C. T.

1966 - Useful Plants of Brazil. - Holden Day, Inc. San Francisco.

MUTHOO, M. K.

1977 - Perspectivas e tendíncias do setor florestal brasileiro, 1975 a 2000.

- IBDF, 2 vols. Serv. Tecn. 8 , Brasilia.

MYERS, Norman

1980 - Conversion of Tropical Moist Forests. - National Acad Science, Washington:
MYERS, Norman

1983 - A Wealth of Wild Species. Westview Press. Boulder, Colorado.

1984 - The Primary Source: Tropical Forests and Our Future. - W.W. Norton \& Co., New York.

1986 - Tropical deforestation and a Mega-extinction Sapams. - In: "Conservation Biology: The Science of Scarcity and Diversity", (Soulé, Ed. 1986), Sinauer Assoc. Mass.

1988 - Tropical Forests and Their Species, Going. - In: " Biodiversity" (Wilson, E.O.-Ed.), pp. 2835, National Acad. Press, Washington.

NAHUZ, M. A. R.

1989 - Deforestation and development: a compound issue for Brazil. - IPT (Publ.1789) Inst. de Pesqs. Tecns., São Paulo.

NAVARRO DE ANDRADE, E.

1961 - O Eucalipto. - 2 ed., Comp. Paul. de Estradas de Ferro, São Paulo.

1941 - The Eucaliptus in Brazil. Journ. of Heredity, vol. 32, n.7, pp. 215-220.

NAVARRO SAMPAIO, A.

1951 - Aplicafónes da madeira de euca. lipto. - Anuário Bŕasileiro de Economia Florestal, n.4, pp. 79-94.

NEW SCIENTIST

1988 - Herb to Fight Malaria. - New Scientist, 15 de set. de 1988.

NOGUEIRA, J. C. B.

1977 - Reflorestamento heterogéneo com esséncias indigenas. - Instituto Florestal, bol. tecn. n.24, São Paulo.

OLIVEIRA, L. A., BRITO Neto, O. e CALADO, M. A. L.

1984 - Preparaçáo de dormentes de madeira para o Projeto Ferro - Carajas. - IPT (Publ. 1513), Inst. de Pesqg. Tecns., São Paulo. 
PAIN, S.

1988 - No Eccope from the Globul Greenhowse. - New Scientist (12 de nov. de 1986), pp.38-43.

PARENTE, $\mathrm{E}$.

1966 - Planear de pulor ecombunico no Cand. - Fortaleza (12 págs.).

PEIXOTO, Rodrigo C. D.

1987 - O carbuo perece ser o contero do probleme, mas os camponeses querem anena a agricultura. - Pará Desenvolvimento, n.22 (julho-dez. de 1987), pp. 80-82, IDESP, Belém, Pará.

PENALBER, A. M. (c outros)

1987 - Elamentos para a elaborageto de una polatica de explomapto racional dos recurses flerestais parn fins de courvogjemento, na drea do Pro. grama Grande Carrajds no Estado do Pard. - Pará Desenvolvimento, n.22 (jul./dez. de 1987), pp. 35-40, IDESP, Belém, Pará.

PEREIRA, J. A. e MAINIERI, C.

1957 - Mradairas do Brucil. - 2 ed., Anúrio Brasileiro de Economia Florestal, n.9, pp. 5-170.

PICCOLO, A. L. G. (e outros)

1972 - Plans invouling plantution of aw. coliptess robusta. - Reviste de Agricultura, vol.47, n.2, Pp. 81-85.

QUERALT, Maria Amélia

1987 - $A$ poltumica prastro do carrogjamanus no Programa Grande Ca. rujis. - Pará Desenvolvimento, n.22, jul./dez de 1987, Pp. 16-22, IDESP, Belém, Pará.

RANKIM, Judy $M$.

1979 - A fiorase tropical como madelo prone desconolnimento ecolbyico no. Amarania - Anais do Simp6sio sobre Ciéncias Básions e Aplicadas. Publ. da ACIESP, n. 19, pp. 112-121, Säo Paulo.
RAVEN, Peter H.

s/d - Our Vanishing Rain Forest

RECORD, S. J.

1925 - Schicolobiums: a promisoing source of pulpmoad. - Tropical Woods, vol.2, pp. 2-5.

RECORD, S. J. e HESS, $R$. W.

1943 - Twrulars of the New World. Yale Univ. Press.

$$
\begin{aligned}
& \text { RENOLD c QUEEN (Eds.) } \\
& 1974 \text { - Ecolegy of Haloplytes. - Aca- } \\
& \text { demic Press, New York. }
\end{aligned}
$$

REIS, Mauro Silva

1983 - Recurses Florestmis no Brovil. Revista do Serviço Público (FUNSEP), ano 40, vol.III, n.4 (out./dez. de 1983), Pp. 7-16, FUNSEP, Brastia.

REITZ, R, KLENN, R e REIS, A.

1978 - Projes madiona de Santar Catarima. - SUDESUL/IBDF, Itajal.

RIZZNNI, Carlos Toledo

' 1971 - Arvores e Madaines Útais do Bra. ill - Monual de Dondrologia Brasilain. Ed. Edigar Blucher e EDUSP, Sso Paulo, (inclui bibliografia selecionada, Pp. 279-286).

1977 - Arnores e madkiras do Brasil. SUPREN. IBGE, Rio de Janeiro.

RIZZINI, C. T. e COMBRA Filho, 1. F.

1988 - Ecoscistemus bravilairos - Braceiliven Ecosysums. - (Tertos). Editora Index, Rio de Janeiro.

ROSILLO-CALLE, F. C HALL, D.

1988 - Brweil Fonds a Sweet Solution to Fuel Sbortages. - New Scientist (19 de maio de 1988), pp. 41-44.

\section{SEPLAN-CODEBAR-SUDAM}

1986 - Problemudica do corrato pegetal na drea do Programa Grande Comejiss. - CODEBAR/SUDAM, Belém, Parí. 
SERRA FILHO, Renato (e outros)

1974 - Lepantamento da Cobertura Vegetal Natural e de Reflorestamento no Estudo de Sato Paulo. -Instituto Florestal, Boletim Técnico IF, n.11, Săo Paulo.

$$
\begin{aligned}
& \text { SIMMONS, N. W. (Ed.) } \\
& 1976 \text { - Evolution of Crop Plants. Long- } \\
& \text { man, New York. }
\end{aligned}
$$

\section{SIMPÓSIO FLORESTAL DA BAHIA}

1973 - Anais do I Simposio Florestal da Babia. - IBDF/ CELAC/ ANCARBA, Secretaria de Agricultura, Bahia, Salvador.

SOCIEDADE BRASILEIRA DE SILVICULTURA

1990 - A Saciedade Brasilecira e seu Patrimbinio Florestal. - SBS, Săo Paulo.

\section{SOCIETE ENCYCLOPEDIQUE UNI-} VERSELLE

1977 - LEncyclopédie de 1 Ecologie. Soc. Encyclop. Univers. (S.E.U.). Librairie Larousse, Paris.

SOULE, M. E. (Ed.)

1986 - Conservation Biology: The Saionce of Scarcity asud Dipersity. Sinauer Assoc. Inc. Publ., Massachussets.

SOUTO, Joảo Jost $\mathrm{P}$.

1985 - Deserto, manemen. - Secremaria da Agricultura (Estado do Rio Grande do Sul), Porto Alegre.

SUTTON e CHADWICK (Eds.)

1983 - Tropical Reain Forest: Ecology and Management

\section{TAVARES, Śrgio}

1959 - Madoiras do Nordeste do Brasil. - Univ. Rural de Pernambuco. monogr. n.5, pp. 9-171, Recife, PE.

THIBAU, C. E.

1986 - Mangjo da florestropical. - I Simpósio do Trópico Úmido, vol. II, pp. 237-244, EMBRAPA CPATU, Belém, Pará.
TIGRE, Carlos de Bastos

1964 - Guia para o reflorestamento do Polgomo das Secas. - Ed. Tip. Minerva. Fortaleza, CE.

1972 - Pesquisa e experimentapto flores. tal para a zoma seca. - MinterDnocs. Fortaleza.

TRICART, Jean

s/d - Problemas de conservaguto de terras e de digunas nos mumiópios de Alegrese e Stao Frasucisco de Assis. - SUDESUL, Relatório de Viagem, Porto Alegre.

1959 - Division moppoclimatique du Bresil atlantigue contral. - Rev. de Gtomorph. Dynamique, vol.9, n.1-2, pp. 1-22, Paris.

UHL, C. e VIEIRA, I. G.

1988 - A actrafubo seletiva de madeiras: impractos ccollogicos an Paragominus. - Pará Desenvolvimento, n.23, Pp. 46-52, Belém, Para.

\section{UNIVERSIDADE DO AMAZONAS}

1979 - Propostas de poltica floressul para a Amazdmia Brasilcira. - Ed. Metro Cúbico, Manaus.

U.S. CONGRESS - Office of Technology Assessment

1987 - Technologies so Maintain Biolo. gical Divarity. - OTA -f-330. U.S. Gov. Printing Office. Washington.

\section{VAN GOOR, C. P.}

1965 - Reflorestomto com confferas no Brasil. - Setor de Invents. Florestais, Minist. de Agricultura (BR), bol. n.9, pp. 5-58, Rio de Janeiro.

VELOSO, H. P. e GOES Filho, L.

s/d - Fitogeografia Brasilcira, classificapto ficiondmico-ecológica da vegenefío neotropical. - Boletim Téenico, n.1, Pp. 1-80, Projeto RADAMBRASIL (Str. Vegereça), Salvador. 
VERGUEIRO, Sérgio

1988 - Roja florestal de castanba. Plano para cultucra de castanha do Brasil em pequenas propriedades. - São Paulo, (xerox).

VICTOR, Mauro Antonio de Moraes (e outros)

1981 - Elenco de Medidas para Promover - Reflorestamento e a Conservajáa dos Recursos Florestais am Sä̃o Paulo. - Parte I - Diagnose. Instituto Florestal, São Paulo (mimeogr.).

VICTOR, Mauro Antonio de Morais

1987 - É Hora de Apaliar o Reflorestamento. - Silvicultura, ano I, maio-junho de 1987.

VICTOR, M. A. M., KRONZA, F. J. N., TIMONI, J. L. e YAMAZOE, G.

1986 - Land classification for industrial afforestation in the State of Sato Paulo, Brazil. - In: "Forest site and productivity", GESSEL, pp. 69-91, Martinus Nijhoff. Publ., Dordrecht.

VOLTATO, E., BARROS, A. F. e DALL'AGNOL, R. e SEABRA, E. J.

1987 - As conseqüincias sociais, cconbmicas e ambientais da siderurgria a carváo" pegetal na Amazbinia Oriental. - Pará Desenvolvimento, n. 22 (jul./dez de 1987), pp. 25-30 (c/subtítulos especificos) Painel IDESP, Belém, Pará.
VOLZ, Richard

1990 - Le Bilan de $\mathrm{CO}_{2}$ des Forests Suisses et de leur Exploitation. Bull. de l'Off. Fed.de l'Environment, des Forêts et du Paysage, n.1 (1990), pp. 16-19.

WILCOX, B. A., BEUCHER, M. EHRLICH, P. H. '

1988 - Tropical Deforestation and Species Extintion: An Assessement of the status of Our Knowletge and Scientifique Needs.-- (Documento preparado para a W.W.F).

WILSON, E. O. (Ed.)

1988 - Biodiversity. - National Academic Press, Washington.

\section{WORLD WIDE FUND FOR NATURE}

1990 - The Importance of Biological Diversity. - A Statement by WWF, Yale Press.

WYATT-SMITH, J.

1987 - The Management of Tropical Moist Forest for the Sustained Production of Timber. -WWF/IUCN/ IIED, London.

YAMAZOE, Guenji (e outros)

1988 - Apaliagato do Programa de Reflorestamento de Pequenos e Médios. - Secr. de Estado do Meio Ambiente - CPRN. (Trab. apres. no I Encontro Brasileiro de Economia Florestal - Curitiba, maio de 1988). Instituto Florestal, Sāo Paulo. 